This item was submitted to Loughborough's Research Repository by the author.

Items in Figshare are protected by copyright, with all rights reserved, unless otherwise indicated.

Fracture toughness modification by using a fibre laser surface treatment of a silicon nitride engineering ceramic

PLEASE CITE THE PUBLISHED VERSION

http://dx.doi.org/10.1007/s10853-010-4743-6

PUBLISHER

(C) Springer

VERSION

AM (Accepted Manuscript)

LICENCE

CC BY-NC-ND 4.0

REPOSITORY RECORD

Shukla, Pratik P., and Jonathan Lawrence. 2019. "Fracture Toughness Modification by Using a Fibre Laser

Surface Treatment of a Silicon Nitride Engineering Ceramic”. figshare. https://hdl.handle.net/2134/7805. 
This item was submitted to Loughborough's Institutional Repository (https://dspace.lboro.ac.uk/) by the author and is made available under the following Creative Commons Licence conditions.

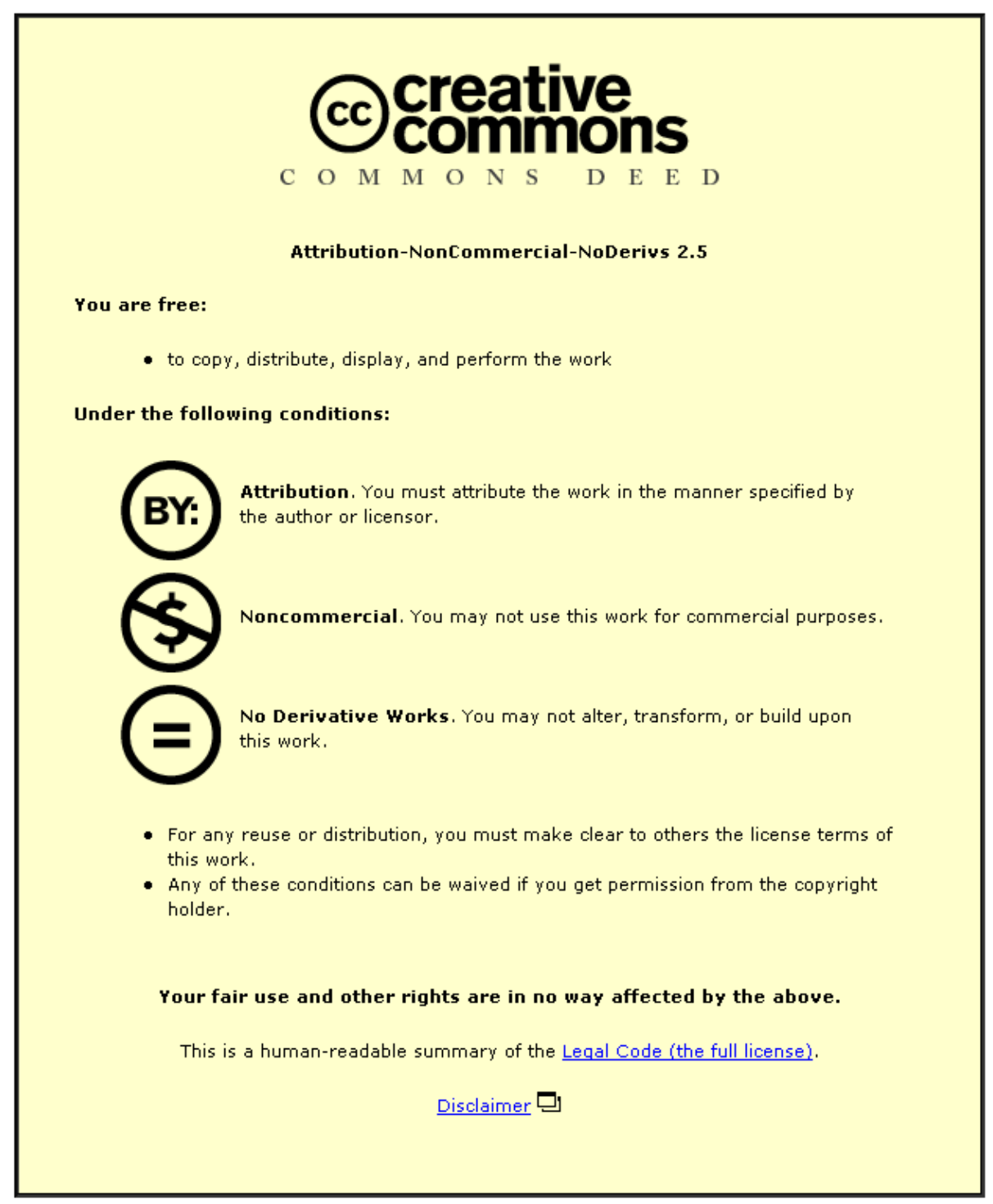

For the full text of this licence, please go to: http://creativecommons.org/licenses/by-nc-nd/2.5/ 


\title{
Fracture Toughness modification by using a Fibre Laser Surface treatment of a Silicon Nitride Engineering Ceramic
}

\author{
P. P. Shukla* and J. Lawrence ${ }^{\text {}}$ \\ ж Loughborough University, Wolfson School of Mechanical and Manufacturing Engineering, Leicestershire, \\ LE11 3TU, United Kingdom. \\ Email: P.Shukla@lboro.ac.uk.
}

Correspondence Address:

Pratik P. Shukla*,

Loughborough University,

Wolfson School of Mechanical and Manufacturing Engineering,

Leicestershire,

LE11 3TU,

United Kingdom,

Email: P.Shukla@lboro.ac.uk,

Direct Line: +44 (0) 1509227592 


\begin{abstract}
Surface treatment of a silicon nitride $\left(\mathrm{Si}_{3} \mathrm{~N}_{4}\right)$ engineering ceramic with fibre laser radiation was conducted to identify changes in the fracture toughness as measured by $K_{1 c}$. A Vickers macrohardness indentation method was adopted to determine the $\mathrm{K}_{1 \mathrm{c}}$ of the $\mathrm{Si}_{3} \mathrm{~N}_{4}$ before and after fibre laser surface treatment. Optical and a scanning electron microscopy (SEM), a co-ordinate measuring machine and a focus variation technique were used to observe and measure the dimensions of the Vickers indentation, the resulting crack lengths, as well as the crack geometry within the as-received and fibre laser treated $\mathrm{Si}_{3} \mathrm{~N}_{4}$. Thereafter, computational and analytical methods were employed to determine the $K_{1 c}$ using various empirical equations. The equation $K_{1 c}=0.016(\mathrm{E} / \mathrm{Hv})^{1 / 2}\left(\mathrm{P} / \mathrm{c}^{3 / 2}\right)$ produced most accurate results in generating $\mathrm{K}_{1 \mathrm{c}}$ values within the range of 4 to $6 \mathrm{MPa} \mathrm{m}^{1 / 2}$. From this it was found that the indentation load, hardness, along with the resulting crack lengths in particular were the most influential parameters within the $K_{1 c}$ equation used. An increase in the near surface hardness of $4 \%$ was found with the $\mathrm{Si}_{3} \mathrm{~N}_{4}$ in comparison with the as-received surface, which meant that the fibre laser treated surface of the $\mathrm{Si}_{3} \mathrm{~N}_{4}$ became harder and more brittle, indicating that the surface was more prone to cracking after the fibre laser treatment. Yet the resulting crack lengths from the Vickers indentation tests were reduced by $37 \%$ for the $\mathrm{Si}_{3} \mathrm{~N}_{4}$ which in turn led to increase in the $\mathrm{K}_{1 \mathrm{c}}$ by $47 \%$ in comparison with the as-received surface. It is postulated that the fibre laser treatment induced a compressive stress layer by gaining an increase in the dislocation movement during elevated temperatures from the fibre laser surface processing. This inherently, increased the compressive stress within the $\mathrm{Si}_{3} \mathrm{~N}_{4}$ and minimized the crack propagation during the Vickers indentation test which led to the fibre laser radiated surface of the $\mathrm{Si}_{3} \mathrm{~N}_{4}$ engineering ceramic to have more resistance to crack propagation.
\end{abstract}

Keywords: Fibre laser, Fracture toughness, $\mathrm{K}_{1 \mathrm{c}}$, Vickers indentation technique, $\mathrm{Si}_{3} \mathrm{~N}_{4}$, Engineering ceramics. 


\section{0 - Introduction}

Crack sensitivity and low fracture toughness can limit the use of $\mathrm{Si}_{3} \mathrm{~N}_{4}$ engineering ceramics, particularly for demanding applications. Nevertheless, the applications of $\mathrm{Si}_{3} \mathrm{~N}_{4}$ have gradually increased on account of the desirable physical properties and longer functional life which often gives the $\mathrm{Si}_{3} \mathrm{~N}_{4}$ engineering ceramics a commercial advantage over the conventional materials in use. Conventional metals and alloys especially can be replaced by engineering ceramics such as $\mathrm{Si}_{3} \mathrm{~N}_{4}$ due to its exceptional mechanical and thermal properties offered. Now, $\mathrm{Si}_{3} \mathrm{~N}_{4}$ ceramics in particular are predominantly being used to manufacture components in the aerospace and automotive industrial sectors [1-5]. Components such as pistons, exhaust manifold, bushings, seals, turbo chargers are being used for high speed diesel engines within the automotives sector [1]. Application of $\mathrm{Si}_{3} \mathrm{~N}_{4}$ in the aerospace industry are namely: valves; bearings; turbine blades; rocket nozzles and rotors [3-5]. For such applications, fracture toughness is an essential property since low fracture toughness in comparison to metals and alloys is one of the disadvantages of the ceramic. Inherently, an increase in the fracture toughness would therefore, lead to an enhancement in the components functional life, better performance which in turn leads to reduction in the maintenance time and cost of the component/part and or the system.

Fracture toughness is considered to be an important property for the $\mathrm{Si}_{3} \mathrm{~N}_{4}$ and other ceramics in general due to their high hardness and brittleness. Materials such as metals and alloys are soft and ductile which in turn would resist cracks at higher stress levels and loading [6-11], whereas hard and brittle materials such as a $\mathrm{Si}_{3} \mathrm{~N}_{4}$ ceramic posses a low fracture toughness and allow crack propagation to occur at lower stresses and loading. This is due to its low ductility, high hardness, caused by the closely packed grains along with a porous structure which increases the crack-sensitivity. This characteristically prevents $\mathrm{Si}_{3} \mathrm{~N}_{4}$ from increasing the movement of dislocations in comparison to that of metals [10-12]. Dislocations are hard to generate within the ceramics due to its strong and highly directional covalent bonds which make it difficult to move the atoms from its lattice positions. 
Mechanical yielding of the $\mathrm{Si}_{3} \mathrm{~N}_{4}$ is also limited due to the porosity and the surface flaws make it crack-sensitive and eventually lead to a much lower resistance to fracture.

$\mathrm{K}_{1 \mathrm{c}}$ is a parameter of fracture toughness and is low for the $\mathrm{Si}_{3} \mathrm{~N}_{4}$ ceramic in comparison with metals and alloys so it would be an advantage if the $\mathrm{K}_{1 \mathrm{c}}$ of the ceramic is enhanced. Through improvement of $\mathrm{K}_{1 \mathrm{c}}$, it is possible to make way for new applications where metals and metal alloys fail due to their low hardness, thermal resistance, co-efficient of friction and wear rate.

This research investigated the use of empirical equations from the literature to calculate the fracture toughness property $\left(\mathrm{K}_{1 \mathrm{c}}\right)$ of a $\mathrm{Si}_{3} \mathrm{~N}_{4}$ engineering ceramic and observed the effects thereon of fibre laser radiation to effect surface treatment. A change in the $K_{1 c}$ has an influence on the materials functionality or diversity to its applications, by improving the $K_{1 c}$ of materials can enhance its functional capabilities such as longer functional life, improved performance under higher cyclic and mechanical loading particularly for demanding applications as previously mentioned. This study also demonstrates a technique to calculate the $\mathrm{K}_{1 \mathrm{c}}$ by employing Vickers indentation test for laser treated CIP $\mathrm{Si}_{3} \mathrm{~N}_{4}$ ceramics. All tested samples were investigated for their top surface hardness, generated crack profiles from the diamond indentations and micro-structural changes before and after the fibre laser treatment.

Shukla and Lawrence [13] recently investigated the effects on the $\mathrm{K}_{1 \mathrm{c}}$ using a fibre laser to surface treat a $\mathrm{ZrO}_{2}$ engineering ceramic which showed changes in the $\mathrm{K}_{1 \mathrm{c}}$ of the $\mathrm{ZrO}_{2}$ ceramic, however, the effects of the fibre laser interaction with $\mathrm{ZrO}_{2}$ are different to that of the $\mathrm{Si}_{3} \mathrm{~N}_{4}$ in comparison. This why the effects of the fibre laser treatment on the $\mathrm{K}_{1 \mathrm{c}}$ of the $\mathrm{Si}_{3} \mathrm{~N}_{4}$ ceramic was explored in this study. Despite the use of industrial lasers such as $\mathrm{CO}_{2}$, Nd:YAG, HPDL and an excimer to process various technical ceramics (see Table 1 for further details); no other investigation except the one of Shukla and Lawrence [13] has been done hitherto by employing a fibre laser to process engineering ceramics. Moreover, the fibre laser was selected because of its shorter wavelength radiation in comparison to the conventional lasers previously used for ceramic processing [14-26]. It would be interesting to 
investigate further the effect of short wavelength on the surface properties of a $\mathrm{Si}_{3} \mathrm{~N}_{4}$ engineering ceramic. Furthermore, despite the Nd:YAG laser wavelength being in the same region as that of the fibre laser, the Nd:YAG laser does not function stably in the continuous wave (CW) mode. This is required for minimizing the thermal shock induced into a ceramic. Fibre lasers also produce high brightness in comparison to the more conventional $\mathrm{CO}_{2}$ and Nd:YAG lasers which generally inhibits deeper penetration, capability of producing finer spot sizes, longer depth of focus, as well as low cost per wattage being exhibited due to it high brightness. As one can see, this investigation is timely as limited research has been conducted by employing fibre lasers to conduct the surface treatment of materials, especially of engineering ceramics.

A previous investigation by Malshe et al. [14] involved the processing of a $\mathrm{Si}_{3} \mathrm{~N}_{4}$ ceramic by employing a $\mathrm{CO}_{2}$ laser to eliminate imperfections within the $\mathrm{Si}_{3} \mathrm{~N}_{4}$ followed by a three-point bending strength study of the ceramic after the $\mathrm{CO}_{2}$ laser surface treatment. The investigation revealed that that imperfection such as surface flaws and porosity was minimized through surface melting of the $\mathrm{Si}_{3} \mathrm{~N}_{4}$ which in turn also enhanced the bending and flexural strength of the $\mathrm{Si}_{3} \mathrm{~N}_{4}$. Sun Li et al. [15] then took this investigation forward to show that a YSiAlON phase in the $\mathrm{Si}_{3} \mathrm{~N}_{4}$ was softened through melting and in-filled the pre-existing fractures to increase the flexural and bending strength. A similar investigation was also conducted by Segall et al. [16] by using a high powered $\mathrm{CO}_{2}$ laser to fill a fractured surface of a thin film $\mathrm{Al}_{2} \mathrm{O}_{3}$ ceramic sheet. Nd:YAG laser machining of structural ceramics was demonstrated by Anoop et al. [17] and discussed the physical phenomenon of material removal of $\mathrm{Al}_{2} \mathrm{O}_{3}, \mathrm{SiC}, \mathrm{MgO}$ and $\mathrm{Si}_{3} \mathrm{~N}_{4}$ ceramics. The use of Nd:YAG laser was also adopted by Hoe and Lawrence [18] on MgO-PSZ ceramics to improve the wettability characteristics for biomedical applications. The results showed melting and solidification of the ceramic led to a changed microstructure and improved wettability through an increase in the surface roughness. Other work by Hoe and Lawrence [19] within biomedical sector also involved improvement of cell adhesion through a $\mathrm{CO}_{2}$ laser surface treatment. Hoe and Lawrence [20] in another investigation used a finite element model (FEM) and compare it to an experimental model to simulate the $\mathrm{CO}_{2}$ laser surface treatment of 
the MgO-PSZ. Their finding revealed accuracy between the two models studied as well as the occurrence of phase changes within the ceramic during the laser beam interaction.

Several other studies discussed the use of industrial lasers to modify the surface of engineering, structural and refractory type ceramics [21-26]. Triantafyllidis et al. [21] investigated a possibility of achieving a crack-free surface of refractory $\mathrm{Al}_{2} \mathrm{O}_{3}$ ceramics using double laser sources: a $\mathrm{CO}_{2}$ and a high powered diode laser (HPDL) by balancing out the thermal gradient and increasing the solidification rate. The results presented crack- and pore-free surfaces along with deep penetration in comparison with the single laser processing. Investigation by Lawrence and Li [22] initially employed a $\mathrm{CO}_{2}$ laser, a Nd:YAG laser, a HPDL and an excimer laser with a $\mathrm{SiO}_{2} / \mathrm{Al}_{2} \mathrm{O}_{3}$ ceramic to investigate the effect of the laser beam absorption on the ceramic and showed that the $\mathrm{CO}_{2}$ laser had the highest absorption followed by the Nd:YAG and then the HPDL. Lawrence and Li [23] then employed a high powered diode laser (HPDL) to surface treat $\mathrm{Al}_{2} \mathrm{O}_{3}$ based refractory ceramic and achieved increased wear life as a dense structure comprising of minor cracks and porosities was found. Another investigation by Lawrence and Li [24] also used the HPDL to process an ordinary Portland concrete (OPC) and showed enhancement in the resistance to chemical attack, water absorption as well as improved wear life of the OPC. Wang et al. [25, 26] published two separate papers on the microstructural and surface density modification of a mixture of $\mathrm{Al}_{2} \mathrm{O}_{3}+\mathrm{ZrO}_{2}+\mathrm{SiO}_{2}$ refractory ceramics system from employing the $\mathrm{CO}_{2}$ laser. The results showed that the laser treatment had refined the microstructure into fine grain dendrites as well as a change in its phase transformation.

\section{0 - Methods for calculating the ceramics $K_{1 c}$}

\section{1 - Vickers indentation technique}

Vickers indentation along with single edge notched beam (SENB), chevron notched beam (CNB) and double cantilever beam (DCB) techniques can be employed to determine the fracture toughness of ceramics. The use of Vickers indentation to determine the fracture toughness parameter $\left(\mathrm{K}_{1 \mathrm{c}}\right)$ of ceramics and glasses from empirical relationships has been demonstrated previously [29-34]. The 
Vickers indentation test has several advantages such as the cost effectiveness and easy set-up as well as being simple and less time consuming in comparison to other indentation techniques.

Measured hardness and the crack lengths from the Vickers indentation test are placed into an empirical equation to calculate the materials $\mathrm{K}_{1 \mathrm{c}}[7,8,13,28]$. The results from the Vickers indentation test can then be applicable to the empirical equations which were derived by Ponton $[7,8]$, Chicot [31] and Liang et al. [32]. The equations derived by Ponton et al. [7, 8] originated from various other authors [33-43]. The equations were however modified and applied specifically to hard and brittle materials such as ceramics and glass by Ponton et al. [7, 8]. The equations have a specific empirical value which is particularly suitable for different ceramics, however, Ponton et al.'s work does not make it clear with regards to which empirical value and equation is more applicable for different ceramics. Preparations of the samples involve polishing in order to create a reflective surface plane (this would mean that the surface has been well polished) [6-8] prior to the Vickers indentation process. There are still constraints with the Vickers indentation techniques as reported by Gong et al. [46], over the more conventional technique applied such as single edge notched beam (SENB) and double-torsion (DT) method as mentioned elsewhere [29, 47-49]. The constraints are: (a) the dependence of the crack geometry on the applied indentation load and the properties of the material; (b) indentation deformation (non-uniform fracture progression or rapid fracture growth) such as lateral cracking; and (c) unsuitable consideration of the effect of Young's modulus and the material hardness [29]. Table 2 presents the literature $\mathrm{K}_{1 \mathrm{C}}$ values for comparison from using the SENB, CNB and DCB technique to determine the fracture toughness of a $\mathrm{Si}_{3} \mathrm{~N}_{4}$ ceramic $[6,50,52]$.

The procedure and steps in order to produce a genuine Vickers indentation test result and produce genuinely valid $\mathrm{K}_{1 \mathrm{c}}$ values are: (a) each indentation must be performed at a sufficient distance from one another. This would avoid the formed cracks to inter-connect and bridge with the other diamond indentations performed on the ceramic surface [53, 54]; (b) a minimum load of $50 \mathrm{~N}$ is recommended; (c) it is ideal to coat the test surface with gold so performed indentations are visible and (d) the test samples should be around 1.5 times larger than the diagonal length of the diamond indentation and 
comprise of minimum porosity. The author also stated that the adjacent indents should be no closer than four times the size of the diamond indentation.

\section{2 - Generation of the cracking profiles during the indentation test}

Liang et al. [32] investigated the $\mathrm{K}_{1 \mathrm{c}}$ of ceramics using the indentation method, followed by applying several equations by various authors as listed in [32]. Liang et al. stated that equations differ as the crack geometry changes (from Palmqvist to median half-penny cracks). He introduced a new equation which was said to be more universal as opposed to the pervious work conducted. Ponton et al.'s formula in comparison was much simplified and was easy to apply. Chicot et al. [31] conducted further investigation by applying two other equations to produce results using materials such as tungsten carbide (Nickel phosphorus treated) and pure silicon. He uses the concept of median halfpenny crack and a Palmqvist crack system to determine the most applicable equation [31]. It was stated that high indenter loads produce a median half-penny crack within the material which is on the edges of the diamond indentation (foot-print produced). This type of crack will always remain connected. A Palmqvist crack is produced during low indenter loading and is of a smaller scale in comparison. The Palmqvist crack will always appear at initial stage of the crack generation during the indentation process, then, a median half-penny crack is produced once the impact of the indenter is exerted. It can be assumed that a median half-penny crack may be the result since the ceramics comprise of high hardness, indicating that high indenter loads are required in order to induced visible and measurable diamond foot prints.

Orange et al. [47] investigated the $\mathrm{K}_{1 \mathrm{c}}$ of $\mathrm{Al}_{2} \mathrm{O}_{3}-\mathrm{ZrO}_{2}$ by comparing the notched beam and the Vickers indentation techniques. Cracking behaviour was observed as Palmqvist and median half-penny crack geometries were found. Low indentation loading produced Palmqvist cracks and with increasing loading median half-penny cracks were found. High micro-cracking was also found with Vickers indentation technique when a fine grain size (0 to $3 \mu \mathrm{m})$ ceramics were tested and with increasing grain size (0 to $5 \mu \mathrm{m})$, the micro cracking was reduced with increase in the $\mathrm{K}_{1 \mathrm{c}}$. With the notched beams technique a higher $\mathrm{K}_{1 \mathrm{c}}$ value was also achieved with a larger grain size [47]. From the work of 
Orange et al. [47] it can be gathered that notched beam indentation technique produced better results in comparison with the Vickers indentation method, although, the reasons behind this were not well justified.

Median half-penny shaped cracks occur when high indentation loads are applied [31, 44, 55]. The profile of a median half-penny shaped cracks are illustrated in Figure 1 (a). It can be predicted that the outcome for most of the crack profiles in this study would be of median half-penny shape. For cracks that are of median half-penny shape the applicable equations differ (see Equations 1-15) [7, 8, 13]. The indention load at which the median half-penny crack occurs for most ceramics is $3 \mathrm{~N}$ [31], this was lower for the loads applied for this investigation. Therefore it would be reasonable to assume that the generated cracks would always be of a half-penny median type crack profile. This indicated that only equation particularly applicable for median-halfpenny cracks should be utilised for this study in order to determine the $\mathrm{K}_{1 \mathrm{c}}$. Figure 1 (b) illustrates a profile of a Palmqvist crack which tends to occur at low indentation loads $[31,55]$.

A Palmqvist crack is part of the median-half penny crack system because when a load above $3 \mathrm{~N}$ is applied the indenter "pop in" occurs, while the already produced Palmqvist crack further develops into a median half-penny crack $[30,55]$. These cracks are shallow and lie in the axis of the indenter as there would be a small extension at the edge of the diamond indenter [55]. Up to $50 \mathrm{~N}$ of indentation loads were used for this work and so it is likely that a Palmqvist crack will occur leading to a halfpenny median crack geometry.

\section{3 - Determination of $K_{1 c}$ using empirical equations}

Equations for median half penny-shaped cracks are usually used for high indenter load applications [36, 37, 40]. One equation is selected to calculate the $K_{1 c}$ value for the treated and as-received samples from applying the equations to real experimental values. The equations were derived by the ceramics geometrical values that were obtained from experimental means, of ceramics and glass [7-8]. Equations 1 to 15 were mentioned in the literature to be applicable for ceramics and glass type 
materials; however, no such equation was defined as applicable for a certain ceramic type; hence the suitability of applying the various equations to $\mathrm{Si}_{3} \mathrm{~N}_{4}$ ceramic was not particularly defined. This is why it was required that an investigation was carried out in order to determine the most employable equation for this study. There were 10 equations selected in this study from various equations discussed in [7, 8, 29], to first determine the $\mathrm{K}_{1 \mathrm{c}}$ of the as-received surfaces of $\mathrm{Si}_{3} \mathrm{~N}_{4}$ and then the laser treated surfaces. The selected equations applicable to calculate the $K_{1 c}$, by using the Vickers indentation methods are [7]:

$$
\begin{aligned}
& \mathrm{K}_{1 \mathrm{c}}=0.0101 \mathrm{P} /\left(\mathrm{ac}^{1 / 2}\right) \\
& \mathrm{K}_{1 \mathrm{c}}=0.0824 \mathrm{P} / \mathrm{c}^{3 / 2} \\
& \mathrm{~K}_{1 \mathrm{c}}=0.0515 \mathrm{P} / \mathrm{c}^{3 / 2} \\
& \mathrm{~K}_{1 \mathrm{c}}=0.0134(\mathrm{E} / \mathrm{Hv})^{1 / 2}\left(\mathrm{P} / \mathrm{c}^{3 / 2}\right) \\
& \mathrm{K}_{1 \mathrm{c}}=0.0330(\mathrm{E} / \mathrm{Hv})^{2 / 5}\left(\mathrm{P} / \mathrm{c}^{3 / 2}\right) \\
& \mathrm{K}_{1 \mathrm{c}}=0.0363(\mathrm{E} / \mathrm{Hv})^{2 / 5}\left(\mathrm{P} / \mathrm{a}^{1.5}\right)(\mathrm{a} / \mathrm{c})^{1.56} \\
& \mathrm{~K}_{1 \mathrm{c}}=0.095(\mathrm{E} / \mathrm{Hv})^{2 / 3}\left(\mathrm{P} / \mathrm{c}^{3 / 2}\right) \\
& \mathrm{K}_{1 \mathrm{c}}=0.022(\mathrm{E} / \mathrm{Hv})^{2 / 3}\left(\mathrm{P} / \mathrm{c}^{3 / 2}\right) \\
& \mathrm{K}_{1 \mathrm{c}}=0.035(\mathrm{E} / \mathrm{Hv})^{1 / 4}\left(\mathrm{P} / \mathrm{c}^{3 / 2)}\right) \\
& \mathrm{K}_{1 \mathrm{c}}=0.016(\mathrm{E} / \mathrm{Hv})^{1 / 2}\left(\mathrm{P} / \mathrm{c}^{3 / 2}\right) \\
& K_{1 c}=0.079\left(P / a^{3 / 2}\right) \log (4.5 a / c) \quad \text { for } 0.5 \leq c / a<4.5 \quad \text { [62] } \\
& K_{1 c}=0.4636\left(P / a^{3 / 2}\right)(E / H v)^{2 / 5}\left(10^{F}\right) \\
& K_{1 c}=0.0141\left(\mathrm{P} / \mathrm{a}^{3 / 2}\right)(\mathrm{E} / \mathrm{Hv}) 2 / 5 \log \left(8.4^{a} / \mathrm{c}\right) \\
& K_{1 c}=0.0232[f(E / H v)] P /\left(a c^{1 / 2}\right)+\text { for } c / a \leq \approx 2.8 \\
& K_{1 c}=0.417[f(E / H v)] P /\left(a^{0.42} c^{1.08}\right) \dagger \text { for } c / a \geq \approx 2.8
\end{aligned}
$$

Note: Equations highlighted in bold were deemed to be appropriate for this investigation.

Ponton et al. [8] state that equation stated by Kelly et al. [43] suggested that equation 10 has an accuracy of 30 to $40 \%$ for ceramics which are well behaved in their indentation response. However, it is first required that the propagation of the crack geometry is understood from performing the Vickers 
indentation test on the as-received $\mathrm{Si}_{3} \mathrm{~N}_{4}$ ceramics as further justified in this paper. It is not made clear as to why this equation was particularly used for the ceramic. It was therefore, required that some of the relevant equations were applied to the tested values from this experiment to determine what sort of results are obtained. Hardness test was performed on the $\mathrm{Si}_{3} \mathrm{~N}_{4}$ assuming that the resulting cracks were of half-penny median type (due to applying a sufficient indentation load). Ten equations were employed as previously stated to establish which particular equation type produces the $\mathrm{K}_{1 \mathrm{c}}$ value that is the nearest to the known value for the as-received $\mathrm{Si}_{3} \mathrm{~N}_{4}$ ceramics which is normally between 4 and $6 \mathrm{MPa} \mathrm{m}^{1 / 2}$.

\section{0 - Experimental Procedure}

\section{1 - Experimental Material}

The material used for the experimentation was cold isostatic pressed (CIP) $\mathrm{Si}_{3} \mathrm{~N}_{4}$ with $90 \% \mathrm{Si}_{3} \mathrm{~N}_{4}, 4 \%$ Yttria, 4\% $\mathrm{Al}_{2} \mathrm{O}_{3}$ and $2 \%$ other, unspecified content by the manufacturer (Tensky International Company, Ltd.). Each test piece was obtained in a bulk of 10 x 10 x $50 \mathrm{~mm}^{3}$ with a surface roughness of $1.56 \mu \mathrm{m}$ (as-received from the manufacturer). A smoother surface than $1.56 \mu \mathrm{m}$ would have much lower surface flaws and micro-cracks and would perform better under the diamond indentation as the resulting crack growth from the Vickers indentation would be smaller but initial experiments showed that polished shinier surfaces (below $1.56 \mu \mathrm{m}$ ) would reflect the beam and would therefore reduced beam absorption into the $\mathrm{Si}_{3} \mathrm{~N}_{4}$ ceramic, hence, the surfaces were not ground and polished. The experiments were conducted in ambient condition at a known atmospheric temperature $\left(20^{\circ} \mathrm{C}\right)$. All surfaces of the $\mathrm{Si}_{3} \mathrm{~N}_{4}$ to be treated were marked with black ink prior to the laser treatment to enhance the absorption and allow the laser beam to further penetrate into the surface. The back ink is generally removed by the fibre laser surface treatment and was not found to have any further effect on the ceramic after the laser surface interaction has taken place.

\section{2 - Fibre Laser Treatment}

A 200 W fibre laser ((SP-200c-002; SPI, Ltd.) emitting a continuous wave (CW) mode beam at a wavelength of $1.075 \mu \mathrm{m}$. Focal position was kept to $20 \mathrm{~mm}$ above the work-piece to obtain a $3 \mathrm{~mm}$ 
spot size. The processing gas compressed air as well as ambient air supplied at a flow rate of $251 \mathrm{~min}^{-}$

1. Programming of the laser was conducted using an SPI software which integrated with the laser system. A $50 \mathrm{~mm}$ line was programmed using numerical control (NC) programming as a potential beam path which was transferred by .dxf file. The nozzle indicated in Figure 2 was removed for all experiments. To obtain an operating window, trials were conducted at the fixed spot size of $3 \mathrm{~mm}$ and by varying the power between 75 and $200 \mathrm{~W}$ and varying the traverse speed between 25 and $500 \mathrm{~mm}$ $\min ^{-1}$. From these trials it was found that 137.5 to $143.25 \mathrm{~W}$ at $100 \mathrm{~mm} \mathrm{~min}^{-1}$ were the ideal laser parameter to use in terms of achieving a crack-free surface as presented in Table 3.

\section{3 - Vickers indentation test method}

An indenter of a specific shape made from a diamond was used to indent the surface of the $\mathrm{Si}_{3} \mathrm{~N}_{4}$ under investigation [6-14]. The diamond was initially pressed on to the as-received surface and the load was then released. A diamond indentation was created thus on the surface which was then measured in size. Thereafter, the surface area of the indentation was placed in to Equation 16 to calculate the hardness value:

$\mathrm{HV}=2 \mathrm{P} \sin [\theta / 2] / \mathrm{D}^{2}=1.8544 \mathrm{P} / \mathrm{D}^{2}$

where $\mathrm{P}$ is the load applied $(\mathrm{kg}), \mathrm{D}$ is the average diagonal size of the indentation in $\mathrm{mm}$ and $\theta$ is the angle between the opposite faces of the diamond indenter being $136^{\circ}$ with less than $\pm 1^{\circ}$ of tolerance. Indentation load of 5, 20 and $30 \mathrm{~kg}$, were applied. The indented surface and the resulting crack lengths were measured using the inbuilt optical microscope of the Vickers indenter (Amstrong Engineers Ltd). This method was then implemented for the fibre laser treated surfaces of $\mathrm{Si}_{3} \mathrm{~N}_{4}$ ceramic. The test samples were placed under the macro indenter and were initially viewed using the built in microscope to adjust the distance between the surface of the work-piece and the diamond indenter. This maintained a sufficient distance during each indentation and allowed a standardized testing method which complies to ISO 6507-1 [54]. 


\section{4 - Measuring the Crack lengths}

The crack lengths generated by employing the Vickers diamond indentation test as presented in Figure 3 (a) and (b) were measured using a contact-less, co-ordinate Measuring Machine (CMM) Flash 200. The ceramic samples were placed under a traversing lens as the optical microscope. The lens traverses in the Y-direction and to adjust the magnification it is also able to move in the Zdirection. Motion in the Y-direction is provided by the bed on which the test-piece is mounted for analysing the surface. The accuracy of the motion system in the $\mathrm{X}$ and $\mathrm{Y}$-direction was $\pm 4.38 \mu \mathrm{m}$ and $5.25 \pm \mu \mathrm{m}$ in the Z-direction. The image appears on the screen as the optical lens traverses above the surface of the test-piece. The scale resolution of the lens was $0.5 \mu \mathrm{m}$. The diamond indentations and the resulting crack lengths were measured by moving the lever in the $\mathrm{X}$ and $\mathrm{Y}$-directions and selecting a starting point on the screen where the crack ends (crack tip) and stopping on the edge of the diamond indentation foot-print (where the crack starts), then measuring the length or the width of the diamond foot-print, followed by measuring the crack length on the other side of the diamond indentation from the edge of the diamond indentation (where the crack starts) to the crack tip (where the crack ends). This measurement was carried out in both the $\mathrm{X}$ and Y-directions.

\section{5 - Determination of the $K_{1 c}$}

The initial investigation used 15 equations to determine which equation type was best suited for calculating the $\mathrm{K}_{1 \mathrm{c}}[7,8]$. The as-received surfaces of the $\mathrm{Si}_{3} \mathrm{~N}_{4}$ were first tested for its hardness. Fifty indentations were made on one surface plane of various test samples of the $\mathrm{Si}_{3} \mathrm{~N}_{4}$ ceramic. Calibrated hardness was then recorded and a mean average was measured of the as-received surfaces. Each indentation and its crack lengths were then viewed at microscopic level by the aid of the optical microscope (Optishot; Nikon Ltd.) to observe the surface morphology. The crack lengths were measured using co-ordinate measuring machine (CMM) (Smartscope Flash 200; OGP Ltd.) CMM and crack geometry was observed by a 3 dimensional (3-D) surface topography using a focus variation technique (Infinite focus; IFM 2.15, Alicona Ltd.). The crack lengths, produced by the indentations were then placed into the various $\mathrm{K}_{1 \mathrm{c}}$ equations with its measured average hardness. Cracking 
geometries were then observed in order to confirm that the cracks generated by the diamond indentation at $5 \mathrm{~kg}$ were of median half-penny crack profile. This insured that Equations (1) to (10) used for median half-penny crack profile were correct. Equation (11) to (15) are used for Palmqvist type crack profile and were not used. Figure 4 and 5 presents an example of a typical surface profile produced from the Vickers diamond indentation using a $5 \mathrm{~kg}$ (see Figure 4) and $20 \mathrm{~kg}$ (see Figure 5) loads. Both showed evidence of median half-penny type crack profiles where an indenter "pop in" indicated in Figure 4 and 5 were exerted and then linear cracks were produced. A Palmqvist crack profile tends to occur with lower indentation loads and had occurred (as indicated from the indenter “pop in”) already in this crack geometry. The concept was more present with higher indentation loading as presented in Figure 5.

Equations 1 to 10 for half-penny median crack system are presented in Table 4 and were initially used to calculate the $\mathrm{K}_{1 \mathrm{C}}$ of the as-received $\mathrm{Si}_{3} \mathrm{~N}_{4}$ engineering ceramic to investigate the most appropriate equation that can be applied to the experimental values for both, the as-received and the fibre laser treated surfaces of the $\mathrm{Si}_{3} \mathrm{~N}_{4}$ engineering ceramic. The results have been tabulated and are as presented in Table 5. The equations were set up using Microsoft Excel which made it easy to be able to input parameters from the full equation. These values were hardness, crack length, Vickers indention load and the Young's modulus. The Young's modulus for the as-received surface and the fibre laser radiated surfaces was kept to $310 \mathrm{GPa}$ for the $\mathrm{Si}_{3} \mathrm{~N}_{4}$. It can be seen that all the values which range between 4 to $6 \mathrm{MPa} \mathrm{m}{ }^{1 / 2}$ for $\mathrm{Si}_{3} \mathrm{~N}_{4}$, would generally allow the equation to be useable for calculating the $\mathrm{K}_{1 \mathrm{c}}$ for the laser treated and as-received surfaces of the $\mathrm{Si}_{3} \mathrm{~N}_{4}$.

Where $\mathrm{P}$ is load $(\mathrm{kg}), \mathrm{N}$ is load in Newton's $(\mathrm{N})$, c is average flaw size $(\mu \mathrm{m})$, a is $2 \mathrm{c}, \mathrm{m}$ is length $(\mathrm{m})$, Hv is the Vickers material hardness value, E is the Young's modulus. (Young's modulus for the asreceived $\mathrm{Si}_{3} \mathrm{~N}_{4}$ was kept to $310 \mathrm{GPa} \mathrm{m}^{1 / 2}$ ). Range (required equation accuracy) is 4 to $6 \mathrm{MPa} \mathrm{m}^{1 / 2}$ for $\mathrm{Si}_{3} \mathrm{~N}_{4}[1,63]$. For all tested samples, the indentation load was 5 and $30 \mathrm{~kg}$. Average of the $\mathrm{K}_{1 \mathrm{c}}$ was obtained by using values from fifty different Vickers indentation tests on one particular surface place 
per sample. This allowed more consistency in calculating the $\mathrm{K}_{1 \mathrm{c}}$ since the values can be used from a bigger pool of data.

The literature value for $\mathrm{K}_{1 \mathrm{c}}$ for the as-received $\mathrm{Si}_{3} \mathrm{~N}_{4}$ is between 4 to $6 \mathrm{MPa} \mathrm{m}^{1 / 2}[1,63]$ so the values that do not lie between the range given for the $\mathrm{Si}_{3} \mathrm{~N}_{4}$ ceramic were not considered as acceptable and therefore, those equations were proved to be less accurate in obtaining the values close to or within the range. The $\mathrm{K}_{1 \mathrm{c}}$ values using Equation 10 were reasonably close to the range for the $\mathrm{Si}_{3} \mathrm{~N}_{4}$ in comparison to the values obtained by the other equations so the equation was most appropriate for use. Based on this other equations were not taken into consideration since the $\mathrm{K}_{1 \mathrm{C}}$ values produced by those equations were far from being within or close to the range.

The Vickers diamond indenter was induced fifty times into the as-received surface plane of the $\mathrm{Si}_{3} \mathrm{~N}_{4}$ ceramic. Hardness values from the indentation test were recorded and the resulting crack lengths were then measured to first calculate the $\mathrm{K}_{1 \mathrm{c}}$ of the untreated surface. This produced fifty $\mathrm{K}_{1 \mathrm{c}}$ values that were obtained from one surface plane. The experimental values obtained were an input into the set Excel spreadsheet such as the indentation load, crack lengths produced by the Vickers diamond indentations and the measured hardness. The equation that generated the closest value within the range (4 to $6 \mathrm{MPa} \mathrm{m}^{1 / 2}$ ) after fifty indentation test was equation 10 . The results of the equation are presented in Table 5 along with their average, standard deviation and range. Despite the average $\mathrm{K}_{1 \mathrm{c}}$ values of the as-received $\mathrm{Si}_{3} \mathrm{~N}_{4}$ ceramic being out of the range (see Table 5), the values obtained by using equations 10 were the closest to the fracture toughness range for the $\mathrm{Si}_{3} \mathrm{~N}_{4}$ ceramic in comparison with the other equations; consequently, this equation was used for all as-received and laser treated $\mathrm{Si}_{3} \mathrm{~N}_{4}$ to determine the $\mathrm{K}_{1 \mathrm{c}}$.

\section{0 - Results and Discussion}

\section{1 - As-received surfaces}

The hardness of $\mathrm{Si}_{3} \mathrm{~N}_{4}$ from applying a $5 \mathrm{~kg}$ load was much lower than the hardness values obtained after applying a load of $30 \mathrm{~kg}$. This was because of the $5 \mathrm{~kg}$ load applied to the material surface area 
resulted into lower penetration of the diamond indentation into the $\mathrm{Si}_{3} \mathrm{~N}_{4}$ as well as the surface area of the diamond footprint also being smaller in dimension that resulted in generating a lower hardness value. The average hardness value for $\mathrm{Si}_{3} \mathrm{~N}_{4}$ was $14.6 \mathrm{GPa}$ with the highest value being $16.42 \mathrm{GPa}$ above the mean and lowest being 13 GPa below the mean. The hardness values of $\mathrm{Si}_{3} \mathrm{~N}_{4}$ using a $5 \mathrm{~kg}$ load comply with the hardness values provided by the manufacturer, however, they were found to be towards a bottom limit. A possible cause of this vast fluctuation in the values may have occurred due to the $\mathrm{Si}_{3} \mathrm{~N}_{4}$ comprising of micro-cracks, porosity as well as impurities on the near surface layer in comparison with the bulk hardness frequently produced non-uniform results.

The results showed minimal difference in the generated crack lengths for $\mathrm{Si}_{3} \mathrm{~N}_{4}$ from applying a $5 \mathrm{~kg}$ load in comparison with the results from applying $30 \mathrm{~kg}$ load. The average crack length was $371 \mu \mathrm{m}$ as shown in Figure 6. Despite the indentation load and the applied force being much smaller in comparison with the $30 \mathrm{~kg}$ load, the material was still cracking in equivalent measure to the results of the trials conducted using a higher load. This clearly indicated that the surface did not exhibit a good response during the indentation test. This could mean that a smoother surface finish was required for the indentation test in order to overcome this problem so that the surface scaring and micro-cracks pre-existing on the $\mathrm{Si}_{3} \mathrm{~N}_{4}$ were minimized and the strength of the top surface layer could be further enhanced for a better indentation response. This also has a possibility of increasing the surface hardness yet at the same time would reduce the resulting cracks from the Vickers diamond footprints and avoid crack bridging between the diamond footprint and the pre-existing surface micro-cracks.

Ponton and Rawlings [7] suggested that a minimum loading of $50 \mathrm{~N}$ must be pressed in order to produce a diamond indent, the minimum loading used herein agrees to the work of Ponton and Rawlings [7]. Although, the loading herein was $49.05 \mathrm{~N}$ and we yet see a diamond indentation with a median half-penny shape profile as presented in Figure 8. Initial experiments using lower indentation loads such as $24.5 \mathrm{~N}$ and $9.8 \mathrm{~N}$ also presented a sufficient indented footprint from the Vickers hardness test. The diamond indentation in Figure 8 is smaller in size when compared with the indentation created by the $30 \mathrm{~kg}$ load. However, the average crack lengths found from using a $5 \mathrm{~kg}$ 
indentation load to some extent were in the same region. The difference between the average values for two test results were $4.31 \%$ and less when considering a larger pool of data. From this it can be gathered that macro hardness indentation test may be more stable at higher indentation loads than lower particularly with hard brittle materials such as $\mathrm{Si}_{3} \mathrm{~N}_{4}$. The overall average $\mathrm{K}_{1 \mathrm{c}}$ using a $30 \mathrm{~kg}$ load was found to be $8.70 \mathrm{MPa} \mathrm{m}^{1 / 2}$ for the $\mathrm{Si}_{3} \mathrm{~N}_{4}$ as presented in Figure 7 also showing the highest value being $12.87 \mathrm{MPa} \mathrm{m}{ }^{1 / 2}$ and the lowest being $5.34 \mathrm{MPa} \mathrm{m}^{1 / 2}$.

The result found for hardness herein when employing a $30 \mathrm{~kg}$ indentation load match with the values provided by the manufacturer and proves that the method used for the hardness calculation and measurement of the crack lengths was valid. Although, the values for the hardness are much smaller than the values provided in the manufacturer's specification when using a $5 \mathrm{~kg}$ load. This was due to the fact that the indentation load was much smaller and produced smaller footprints of the diamond which exerted lower force to the surface and reduced the end value of the $K_{1 c}$. The average $K_{1 c}$ was found to be $1.71 \mathrm{MPa} \mathrm{m}^{1 / 2}$ for the $\mathrm{Si}_{3} \mathrm{~N}_{4}$ as presented in Figure 9 also showing the highest value being 3.06 MPa $\mathrm{m}^{1 / 2}$ and the lowest being 0.55 MPa $\mathrm{m}^{1 / 2}$.

The hardness can become much higher if the surfaces were ground and polished prior to the Vickers indentation test as previously stated. This would minimizes the surface micro-cracks and result in obtaining a better consistency in achieving the hardness value and the resulting crack lengths but surfaces could not be ground and polished in this case as the initial studies showed that grinding and polishing resulted to the $\mathrm{Si}_{3} \mathrm{~N}_{4}$ ceramic becoming smooth and shiny which in turn has the tendency to produced high laser beam reflection. Furthermore, grinding and polishing could not be conducted after the fibre laser treatment as it removed the newly formed layer and would also induce some degree of residual stress into the ceramic as stated by Sun Li et al. [15] which would not do justice to the fibre laser radiated surface during the Vickers indentation test, hence, all surfaces were tested asreceived for the indentation study prior to and after the fibre laser treatment. 


\section{2 - Fibre laser treated surfaces}

The mean hardness found was $11.32 \mathrm{GPa}$ on the fibre laser treated $\mathrm{Si}_{3} \mathrm{~N}_{4}$. The highest value above the mean was $14.21 \mathrm{GPa}$ and the lowest being $7.73 \mathrm{GPa}$. There was a 4\% difference between the average hardness values obtained from the fibre laser treatment in comparison with the average hardness values obtained by the as-received surface (see section 4.1). The fibre laser treatment with an effective increase in hardness. In general, an increase in the hardness of a material indicates that the surface has become more brittle and therefore prone to cracking and fracture. This would manifest as longer crack lengths on the corners of the diamond indentations. This however, did not occur as the average crack lengths on the fibre laser treated surface were much reduced in comparison to the crack length of the as-received surface, $242 \mu \mathrm{m}$ compared to $387 \mu \mathrm{m}$ respectively (see example in Figure 10). The fibre laser treated surfaces also comprised of much smaller cracks in comparison with the as-received surface as is evident in Figure 11.

The increase in the hardness and decrease in the crack lengths following the fibre laser surface treatment can be by the event of strain hardening taking place as result of the fibre laser- $\mathrm{Si}_{3} \mathrm{~N}_{4}$ surface interaction. The of strain hardening through movement of dislocations at elevated temperatures which could induce compression into the surface and sub-surface of the ceramic and through the effect of transformation hardening.

If one considers the heat generated from irradiation by the fibre laser beam is likely to have caused the $\mathrm{Si}_{3} \mathrm{~N}_{4}$ to transform from the $\alpha$ to $\beta$ state at $1600{ }^{\circ} \mathrm{C}$, as stated by Jiang et al. [64]. This in turn would have caused the observed increase in the hardness of the $\mathrm{Si}_{3} \mathrm{~N}_{4}$ to $35.31 \mathrm{GPa}$. Since, the temperature during the fibre laser processing has been found to be much higher than $1600^{\circ} \mathrm{C}$ [65], phase transformation of $\alpha$ - $\beta$ phase will inherently occur after the fibre laser surface treatment of the $\mathrm{Si}_{3} \mathrm{~N}_{4}$.

An investigation by Moon et al. [66] found that the fracture toughness of $\mathrm{Al}_{2} \mathrm{O}_{3}$ and $\mathrm{Si}_{3} \mathrm{~N}_{4}$ ceramics was improved considerably by generating dislocations within the ceramics by plastic deformation (shot blasting) and then annealing to temperatures of $1500^{\circ} \mathrm{C}$. Work by Shukla and Lawrence [65] 
showed that the fibre laser surface processing of $\mathrm{Si}_{3} \mathrm{~N}_{4}$ occurred above $2000^{\circ} \mathrm{C}$ and could have led to an increase in the hardness as the movement of dislocations at elevated temperatures will have induced residual stress into the ceramic in the form of compression. At the same time the $\mathrm{Si}_{3} \mathrm{~N}_{4}$ would have decomposed up to $1900^{\circ} \mathrm{C}$ and above, with a material removal of over $100 \mu \mathrm{m}$ at temperature up to $2000^{\circ} \mathrm{C}$ and above. Owing to the fibre laser induced compression (see Figure 11); the tension would have needed to overcome the compression in order to produce a fracture. Therefore, the cracking of the $\mathrm{Si}_{3} \mathrm{~N}_{4}$ was much smaller in comparison to the as-received surface. This meant that the tension induced by the $5 \mathrm{~kg}$ load to produce the crack on the fibre laser treated surface was much smaller than the induced compression. This rational goes some way to explaining the reason why smaller crack lengths have been found on the fibre laser treated $\mathrm{Si}_{3} \mathrm{~N}_{4}$ surface in comparison with the as-received surface.

Residual stress is generally found by using the X-ray diffraction (XRD) method on the $\mathrm{Si}_{3} \mathrm{~N}_{4}$ ceramics [67]. However, in this case, the fibre laser treated surface of the $\mathrm{Si}_{3} \mathrm{~N}_{4}$ ceramic becomes amorphous after decomposition of the $\mathrm{Si}_{3} \mathrm{~N}_{4}$ at $1900^{\circ} \mathrm{C}$. Although X-rays diffract from the amorphous layer, there are yet no sharp diffraction peaks that can be found and an amorphous hump with a broad profile is found whose position can be determined by the average intermolecular spacing but this is not ideal for residual stress measurement and therefore compressive residual stress was only predicted based on the increase in hardness and decrease in the crack length of the ceramic after the fibre laser treatment in this study.

The average $\mathrm{K}_{1 \mathrm{c}}$ value for the $\mathrm{Si}_{3} \mathrm{~N}_{4}$ after the fibre laser treatment was $3.25 \mathrm{MPa} \mathrm{m}{ }^{1 / 2}$. The highest $\mathrm{K}_{1 \mathrm{c}}$ value obtained above the mean was $6.03 \mathrm{MPa} \mathrm{m}^{1 / 2}$. The lowest value below the mean for was 2.20 MPa $\mathrm{m}^{1 / 2}$ for $\mathrm{Si}_{3} \mathrm{~N}_{4}$ as presented in Figure 12 and Table 4. The $\mathrm{K}_{1 \mathrm{c}}$ values for the fibre laser treated $\mathrm{Si}_{3} \mathrm{~N}_{4}$ were enhanced by $47 \%$ in comparison with that of the as-received surfaces. The values in Figure 12 mainly fluctuate due 37\% reduction in the crack lengths found for the fibre laser treated. In those areas where the $\mathrm{K}_{1 \mathrm{c}}$ is high, indicate that the localized near surface layer has more resistance to crack propagation under cyclic loads or during the onset of any tensile stresses. 
Indentation fracture toughness method is heavily dependent on the local micro-structural changes and its influence. Hence, the microstructure of the fibre laser radiated and as-received surfaces of the $\mathrm{Si}_{3} \mathrm{~N}_{4}$ ceramic are presented un Figure 13 (a) - (d). The grains can be seen in Figure 13 (b) and range between 8 to $15 \mu \mathrm{m}$. Surface flaws, cavity and micro porosity as well as morphology are also present in the image. Figure 13 (c) and (d) show the microstructure of the fibre laser radiated $\mathrm{Si}_{3} \mathrm{~N}_{4}$ ceramic and is somewhat different to that of the as-received surface. It can be seen that considerable amount of material removal has occurred from the laser beam interaction after some degree of decomposition taking place. The removal of the surface was around $101 \mu \mathrm{m}$ by using compressed air assist gas. This has produced a degree of oxide layer from the exposure to the atmosphere and would have also changed the composition of the laser treated area of the $\mathrm{Si}_{3} \mathrm{~N}_{4}$ as further discussed. The surface morphology also shows a reduction in the porosity and the surface flaws that are apparent particularly in Figure 13 (a). This may have caused the increase in hardness with reduced crack length which in turn increases the $\mathrm{K}_{1 \mathrm{c}}$.

Consideration should also be given to the processing conditions of the ceramic as this will vary the depth of indentation and the relative cracking geometry underneath the diamond indenter depending on the sintering conditions of the ceramic and the relative density. In this case the $\mathrm{Si}_{3} \mathrm{~N}_{4}$ was not sintered and therefore was not fully dense $\left(3.15 \mathrm{~g} / \mathrm{cm}^{3}\right)$ [68] compared to a fully sintered $\mathrm{Si}_{3} \mathrm{~N}_{4}(3.60$ $3.80 \mathrm{~g} / \mathrm{cm}^{3}$ ) [63]. The partially sintered or un-sintered $\mathrm{Si}_{3} \mathrm{~N}_{4}$ would be more porous in comparison to that of a fully sintered $\mathrm{Si}_{3} \mathrm{~N}_{4}$ and therefore would be low in strength which also means that the cracking geometry would be longer in comparison to the fully dense $\mathrm{Si}_{3} \mathrm{~N}_{4}$. The depth of the indentation is dependent on the indentation load applied. At $30 \mathrm{~kg}$ the depth of the indentation was around $30.05 \mu \mathrm{m}$ on the laser treated track. At $5 \mathrm{~kg}$ of load, the depth was $14.84 \mu \mathrm{m}$ on the laser treated track. The depth of the laser treated track ranged from 100 to $120 \mu \mathrm{m}$ and in relation to the diamond indentation depth was much deeper. This meant that the diamond indentation was not fully penetrating through the fibre laser radiated surface to make contact with the sub-surface where the condition of the sub-surface micro-structure would fully affect the cracking geometry of the fibre 
laser radiated surface. The condition of the sub-surface would affect the crack geometry for the instance where the diamond indenter is penetrating through the modified surface layer.

Table 6 presents the results obtained by the as-received surface and the fibre laser treated surface of the $\mathrm{Si}_{3} \mathrm{~N}_{4}$ engineering ceramic. Values for the fibre laser treated surface were compared to the values of the as-received surface indented using a $5 \mathrm{~kg}$ load to determine the percentage rise and decrease. Vickers indentation method offers many advantages for calculating the $\mathrm{K}_{1 \mathrm{c}}$. Nevertheless, it has many flaws. Those are the results obtained from the hardness test heavily depending on the operator's ability to detect the crack lengths and its geometry. The ceramics ability to the indentation response and the surface conditions that were used during the indentation test as smoother surfaces would result to higher surface strength and influences the hardness value and the resulting crack lengths. The $\mathrm{K}_{1 \mathrm{c}}$ results could be much more accurate if a consistent surface hardness value was obtained along with its crack geometry which could be found from employing other indentation techniques as well as various other methods by using other existing equations would also produce variation in the $\mathrm{K}_{1 \mathrm{c}}$ value.

The $\mathrm{K}_{1 \mathrm{C}}$ value would also be affected if the effect of Young's modulus is to be considered. The fibre laser radiation would increase the stress and strain ratio of the ceramic on one plane in comparison to the other planes, which may then produce anisotropy within the plane that is normal to the direction of the laser treatment as opposed to the remaining untreated material in other planes. The ceramic would also become anisotropic as the grain structure found from the SEM (see Figure 13) images does not show any regularity in comparison to the one of the as-received surface this would indicate that the laser treated surface may be anisotropic. As well as the changed composition and reduction in porosity, the change in the Young's modulus would also occur due to an interlocking the microstructural produced by the fibre laser radiation. The interlocked microstructure will produce refinement in surface flaws and covering of the micro-cracks. This in turn will create a denser surface layer and affect the elastic property by increasing the stress resistance. If the Young's is raised due to such effects then the end $K_{1 C}$ value would also increase as the Young's modulus is an effective 
parameter into the $\mathrm{K}_{1 \mathrm{C}}$ equation so it is likely that the influence of the Young's modulus would be significant in calculating $\mathrm{K}_{1 \mathrm{c}}$ values in this investigation. 


\section{0 - Conclusions}

Various empirical equations were used to calculate the fracture toughness parameter $\left(\mathrm{K}_{1 \mathrm{C}}\right)$ of the asreceived surfaces of the $\mathrm{Si}_{3} \mathrm{~N}_{4}$ engineering ceramic to investigate the most suitable equation. It was found that equation: $\mathrm{K}_{1 \mathrm{c}}=0.016(\mathrm{E} / \mathrm{Hv})^{1 / 2}\left(\mathrm{P} / \mathrm{c}^{3 / 2}\right)$ by Anstis, Chantikul, Lawn \& Marshall was the most relevant equation to use for the $\mathrm{Si}_{3} \mathrm{~N}_{4}$ ceramic. The changes in the hardness demonstrated that the hardness acted as an influential parameter in changing the surface $\mathrm{K}_{1 \mathrm{c}}$ value. The average surface hardness of the as-received surface was found to be $10.85 \mathrm{GPa}$ with the average crack length being $387 \mu \mathrm{m}$ using a $5 \mathrm{~kg}$ indentation load, which led to producing an average surface $\mathrm{K}_{1 \mathrm{c}}$ value of 1.71 MPa $\mathrm{m}^{1 / 2}$. It was found that higher indentation loads produced bigger diamond footprints and generated higher crack lengths. However, the $\mathrm{K}_{1 \mathrm{c}}$ values were also increased from applying higher load due to the indentation load also being an important function of the $\mathrm{K}_{1 \mathrm{c}}$ equation when employing the Vickers indentation method for determining the ceramics $\mathrm{K}_{1 \mathrm{c}}$.

Comparison of the as-received surface with the fibre laser treated surface showed improvement in the $\mathrm{K}_{1 \mathrm{c}}$ value of the top (near) surface layer of the fibre laser treated $\mathrm{Si}_{3} \mathrm{~N}_{4}$ engineering ceramic. The hardness was increased by $4 \%$, however, the crack lengths were yet reduced by $37 \%$. The average hardness found with the fibre laser treated surface was $11.32 \mathrm{GPa}$ along with the average crack length being $242 \mu \mathrm{m}$. This resulted in boosting the $\mathrm{K}_{1 \mathrm{c}}$ value to $3.25 \mathrm{MPa} \mathrm{m}^{1 / 2}$ which was $47 \%$ higher in comparison to the as-received surface. This was due to the $\mathrm{Si}_{3} \mathrm{~N}_{4}$ surface radiated by the fibre laser had induced surface compression into the ceramic and produced an interlocking micro-structure. Through this, a reduction in the crack lengths from the after the diamond indentation was also found. The small increase in the hardness after the fibre laser treatment is believed to have occurred due to the effect of strain hardening through movement of dislocations at elevated temperatures which would also induce compressive residual stress through increase in the dislocation movement. As well as the transformation hardening where the $\mathrm{Si}_{3} \mathrm{~N}_{4}$ ceramic had changed from $\alpha-\beta$ phase at $1600^{\circ} \mathrm{C}$ and increase the hardness. On account of this, smaller cracks were produced during the Vickers diamond 
indentation as the induced tension by the indentation force would have to overcome the induced compression by the fibre laser surface treatment. 


\section{0 - References}

1 Richardson D, (2006) Modern Ceramic Engineering. Third Edition, published by CRC Press, Taylor \& Francis Group, New York

2 Kawamura H, (1999) New Perspectives in Engine Applications of Engineering Ceramics. Science of Engineering Ceramics II, International Symposium 161: 9-16

3 Mikijelj B, Mangels J (2000) SRBSN Material Development for Automotive Applications. $7^{\text {th }}$ International Symposium of Ceramic Materials and Components for Engines, U.K.

4 Mikijelj B, Mangels J, Belfield E (2002) High Contact Stress Applications of Silicon Nitride in Modern Diesel Engines. Institution of Mechanical Engineers Fuel Injection System Conference, London

5 Mangels J (2006) A proven Ceramic Material for Engine Applications. Institution of Mechanical Engineers, Fuel Injection System Conference, London

6 Shukla PP (2007) Laser Surface Treatment of Silicon Nitride using contact-less energy beams. MSc by Research thesis. Coventry University, United Kingdom

7 Ponton CB, Rawlings RD (1989) Vickers indentation fracture toughness test, Part 1 - Review of literature and formulation of standardised indentation toughness equations. Materials Science and Technology 5: 865- 872

8 Ponton CB, Rawlings RD (1989) Vickers indentation fracture toughness test, Part 2 - Review of literature and formulation of standardised indentation toughness equations. Materials Science and Technology 5: 961- 976

9 McColm IJ (1990) Ceramic Hardness. Platinum Press, New York

10 Mitchell TE (1985) Dislocations in Ceramics. Materials Science and Technology 1: 994 - 949

11 Castaing J, Veyssiere P (1985) Core Structure Dislocations in Ceramics. Gordon and Breach Science Publishers Inc and OPA Ltd U.K 12: 213 -227 
12 Castaing J (1995) Plastic Deformation and dislocations in ceramic materials. Radiation Effects and Defects in Solids. Gordon and Breach Science Publishers Inc and OPA Ltd, S.A, 137: 205 - 212

13 Shukla PP, Lawrence J (2009) On the Fracture Toughness of a Zirconia Engineering Ceramic and the Effects thereon of surface processing with fibre laser radiation. Proceedings of the IMechE Part B, 224: (in press)

14 Malshe A, Sun Li, Jiang W, McCluskey WP (2006) Effect of $\mathrm{CO}_{2}$ Laser Surface Processing on Fracture Behaviour of silicon Nitride Ceramic. Journal of engineering materials and technology 128: $460-467$

15 Sun Li, Malshe AP, Wen-ping Jiang, Mccluskey PH (2006) Experimental investigation of laser surface processing of flexure silicon nitride ceramic. Transactions of Nonferrous Materials Society of China 16: 558-565

16 Segall AE, Cai G, Akarapu R, Ramasco A (2005) Fracture control of unsupported ceramics during laser machining using a simultaneous prescore. Journal of Laser Applications 17 (Issue 1): 57-62

17 Anoop N, Samant, Narendra B, Dahotre (2009) Differences in physical phenomena governing laser machining of structural ceramics. Ceramics International 35: 2093-2097

18 Hao L, Lawrence J (2006) Effects of Nd:YAG laser treatment on the wettability characteristics of a zirconia-based bioceramic. Optics and lasers in engineering 44: 803- 814

19 Hoe L, Lawrence J, Chian K S (2005) Osteoblast cell adhesion on a laser modified zirconia based bioceramic. Journal of Material Science: Materials in Medicine 16: 719- 726

20 Hao L, Lawrence J (2006) Numerical modeling of the laser surface processing of magnesia partially stabilized zirconia by the means of three-dimensional transient finite element analysis. Proceedings of the Royal Society A 462 (no 2065): 43-57

21 Triantafyllidis D, Lin L, Stott FH (2002) Surface treatment of alumina-based ceramics using combined laser sources. Applied surface science 186: 140 - 144

22 Lawrence J, Li L (2002) On the Differences between the Beam Interaction Characteristics of $\mathrm{CO}_{2}$, Nd:YAG, Excimer and High Power Diode Lasers with a $\mathrm{SiO}_{2} / \mathrm{Al}_{2} \mathrm{O}_{3}$ Ceramic. Lasers in Engineering, 12 (Issue 2): 81-93 
23 Lawrence J, Li L (2003) Augmentation of the mechanical and chemical resistance characteristics of an $\mathrm{Al}_{2} \mathrm{O}_{3}$-based refractory by means of high power diode laser surface treatment. Journal of Materials Processing Technology 142: 461 - 465

24 Lawrence J, Li L (2003) The enamelling of concrete for improved performance characteristics by means of high power diode laser interaction. Journal of Materials Processing Technology 138: 551559

25 Wang HA, Wang WY, Xie CS, Song WL, Zeng DW (2004) $\mathrm{CO}_{2}$ laser-induced structure changes on an alumina-mullite-zirconia refractory. Applied Surface Science 223: 244 - 251

26 Wang HA, Wang WY, Xie CS, Song WL, Zeng DW, (2003) Micro-structural characteristics of $\mathrm{Al}_{2} \mathrm{O}_{3}$-based refractory containing $\mathrm{ZrO}_{2}$ induced by $\mathrm{CO}_{2}$ laser melting. Applied surface Science 221: 291- 301

27 Delmdahl R, Pätzel R, (2008) Pulsed laser deposition—UV laser sources and applications. Applied Physics A, 93: 611- 615.

28 Shukla PP, Lawrence J, (2009), Laser treatment of engineering ceramics and the effects thereof on the fracture toughness. Proceeding of ICALEO 2009, Orlando: FL

29 Liang KM, Orange G, Fantozzi G 1990 Evaluation by indentation of fracture toughness of ceramics. Journal of material Science 25: 207 - 214

30 Matsumoto RKL, (1987) Evaluation of fracture toughness determination method as applied to ceria - stabilized tetragonal Zirconia poly-crystal. Journal of American Ceramic Society 70: 366 - 368

31 Chicot D (2004) New Development for fracture toughness determination by Vickers indentation. Materials Science and Technology 20: 877- 884

32 Liang KM, Orange G, Fantozzi G (1988) Crack resistance and fracture toughness of Alumina and Zirconia ceramics: Comparison of notched- beam and indentation technique. Science Ceramics $14^{\text {th }}$ International Conference 14: 709- 714 
33 Exner HE (1989) The Influence of Sample Preparation on Palmqvist's Method for Toughness Testing of Cemented Carbides. Transactions of the Metallurgical Society of AIME 245 (4): 677 683

34 Marion RH (1979) In fracture mechanics applied to brittle materials. STP 678 (Ed S. W Freiman), PA, ASTM:103 - 111, Philadelphia

35 Evans AG, (1976) Wilshaw TR Quasi static particle damage in brittle solids. Acta Metall 24: 939 956

36 Evans AG, Charles EA (1976) Fracture Toughness Determinations by Indentation. Journal of American Society 59 (7 - 8): $371-372$

37 Lawn BR, Evans AG, Marshall DB (1980) Elastic/ Plastic Indentation Damage in ceramic: The Meadian/ Radial Crack System. Journal of American Ceramic Society 63 (9-10): 574 - 581

38 Marshall DB (1983) Failure from contact induced surface flaws. Journal of American Ceramic Society 66: $127-131$

39 Anstis GR, Chantikul P, Lawn BR, Marshall DB, (1981) Journal of American ceramic Society 64: $533-538$

40 Niihara K, Morena R, Hasselman DPH (1982) Evaluation of $\mathrm{K}_{1 \mathrm{c}}$ of brittle solids by the indentation method with low crack-to-indent ratios. Journal of material Science Literature 1: 13 - 16

41 Tani T, Miyamoto Y, Koizumi M (1986) Grain Size Dependences of Vickers micro hardness and fracture toughness in $\mathrm{Al}_{2} \mathrm{O}_{3}$ and $\mathrm{Y}_{2} \mathrm{O}_{3}$ ceramics. Ceramics International 12(P1): 33 - 37

42 Hoshide T (1993) Grain fracture model and its application to strength evaluation in engineering ceramics. Engineering fracture mechanics 44 (No 3): 403 - 408

43 Kelly JR, Cohen ME, Tesk JA (1993) Error Biases in the Calculation of Indentation fracture Toughness for Ceramics. Journal of American Ceramic Society 76 (10): 2665 - 2668.

$44 \mathrm{Li}, \mathrm{Z}$, Gosh A, Kobayashi AS, Bradt RC, (1989) Indentation fracture toughness of sintered silicon nitride in the Palmqvist crack regime. Journal of American ceramic Society 72: 904 - 911 
45 Strakna TJ, Jahanmir S (1995) Influence of grinding direction on Fracture strength of silicon nitride. Machining of advanced Materials 208: 53 - 64

46 Gong J (1998) Determining indentation toughness by incorporating true hardness into fracture mechanics equations. Journal of European Ceramic Society 19: 1585 - 1592

47 Orange O, Liang KM, and Fantozzi G (1987) Crack Resistance and fracture toughness of alumina and Zirconia ceramics: comparison of notched beam and indentation technique. Science of ceramics 14 (PT 7 - 9): $709-14$

48 Glandous JC, Rouxl T, Qiu T (1991) Study of the Y- TZP toughness by an indentation method. Ceramic International 17: 129 -135

49 Fischer H, Waindich A, Telle R (2006) Influence of preparation of ceramic SEVNB specimens on fracture toughness testing results. Academy of dental material, Science direct 24: $618-622$

50 Gosotsi GA, (2000) Fracture toughness studies on V-notched ceramic. Strength of materials, 32, No.1: $81-85$.

51 Jonathan A, Salem, Shannon JL, Jr, Jenkins MG, (1992) Some observations in fracture toughness, ASTM International, 9 -25.

52 Anstis GR, Chantikul P, Lawn BR, Marshall DB, (1980) Acritical evaluation of indentation technique for measuring fracture toughness, I, direct measurement. Journal of American ceramic society, $64: 533-538$.

53 Lawn BR, Swain MV (1975) Microfracture: Beneath Point In- dentations in Brittle Solids. Journal of material science 10: $113-122$

54 British Standards (2005) Vickers Hardness Test- Part 2- Verification and Calibration of testing Machines. Metallic Materials - ISO 6507-1

55 Lawn BR, Wilshaw TR (1975) Indentation fracture: principles and application. Journal of material science 10: 1049 - 1081

56 Lawn BR, Fuller ER (1975) Equilibrium penny-like cracks in indentation fracture. Journal of material Science 10: 2016 - 2024 
57 Lankford J (1982) Indentation microfracture in the Palmqvist crack regime: implication for fracture toughness evaluation by the indentation method. Journal of material science Letters 1: 493-495

58 Laugier MT (1985) The elastic/plastic indentation of ceramics. Journal of Material Science letters 4: $1539-1541$

59 Tanaka K (1987) Elastic/plastic indentation hardness and indentation fracture toughness: The inclusion core model. Journal of material Science 22: 1501 - 1508

60 Evans AG (1979) Fracture mechanics applied to brittle materials. STP 678, (ed S.W. Freiman), Philadelphia, PA ASTM PP: 112-135

61 Blendell JE (1979) PhD thesis. Massachusetts Institution of technology

62 Miranzo P, Moya JS (1984) Elastic/plastic indentation in ceramics: a fracture toughness determination. Ceramic International 10 (4): 147 - 152

63 Granta Design Ltd. CES selector, version 5.1. Cambridge, UK, 2008. www.granta.co.uk.

64 Jiang JZ, Kragh F, Frost DJ, Stahl K, Lindelov H (2001) Hardness and thermal stability of cubic silicon nitride. Journal of physics condensed matter 13 (No 22): L515-L520

65 Shukla PP, Lawrence J (2009) Characterization of fibre laser treated engineering ceramics. Proceedings of ICALEO-09, FL, USA

66 Moon W, Ito T, Uchimura S, Saka H (2004) Toughening of ceramics by dislocation sub-boundaries. Material Science and Engineering A 387 - 389: 837 - 839

67 Pfeiffer, Frey W (2002) Shaping the future - damage or benefits. Fraunhofer Institute for Mechanics of Materials ICSP - 8: Germany

68 Tensky International Co. Ltd. (2009) Tensky International technical specification. www.tensky.com.tw 
Plane stress fracture toughness $=$ $\mathbf{K}_{\mathbf{c}}$

Fracture Toughness $=$

$K_{1 c}$

Carbon Dioxide $=$

$\mathrm{CO}_{2}$

Continuous Wave $=$

CW

Hardness =

Hv

Young's Modulus =

E

Newton's =

$\mathbf{N}$

Average Flaw Size $=$

c

Load $(\mathrm{kg})=$

$\mathbf{P}$

Load Impact $=$

Pc

Interior Cracks =

Ic

Metre per minute $=$

$\mathbf{m} \min ^{-1}$

Hot Isostatic Pressed =

HIP

Cold Isostatic Pressed =

CIP

Oxygen $=$

$\mathbf{O}_{2}$

Silicon Nitride $=$

$\mathrm{Si}_{3} \mathrm{~N}_{4}$

Zirconia Oxide $=$

$\mathrm{ZrO}_{2}$

Alumina $=$

$\mathrm{Al}_{2} \mathrm{O}_{3}$

Silicon Carbide $=$

Sic

Magnesia Oxide $=$

MgO

Partially Stabilized Zirconia =

PSZ

Silicon Dioxide $=$

$\mathrm{SiO}_{2}$

Kilo gram =

kg

Mega Pascal =

MPa

Giga Pascal $=$

GPa 
Micro Metre =

$\mu \mathrm{m}$

Meters $=$

m

Meter Cubed =

$\mathbf{m}^{2}$

Millimetres =

$\mathbf{m m}$

Litres $=$

Co-Ordinate Measuring Machine =

CMM

Delta $=$

Beta $=$

B

Degrees Centigrade =

${ }^{\circ} \mathbf{C}$

Numerical Control =

NC

Theta $=$

$\boldsymbol{\theta}$

Average diagonal size $=$

D

Sailon $=$

YSiAION

Neodimium Yitrium Aluminium Garnet $=$

Nd:YAG 


\section{List of Tables}

Table 1: The comparison and suitability of using various industrial lasers to surface process

engineering ceramics $[22,27,28]$.

\begin{tabular}{|c|c|c|c|c|c|}
\hline \multirow[b]{2}{*}{$\begin{array}{c}\text { Process } \\
\text { parameters }\end{array}$} & \multicolumn{5}{|c|}{ Type of lasers, conditions and suitability to process ceramics in general } \\
\hline & $\begin{array}{c}\mathrm{CO}_{2}(\mathrm{CW}) \\
10.06(\mu \mathrm{m})\end{array}$ & $\begin{array}{c}\text { Nd:YAG (CW) } \\
1.064(\mu \mathrm{m})\end{array}$ & $\begin{array}{l}\text { Fibre (CW) } \\
1.075(\mu \mathrm{m})\end{array}$ & \begin{tabular}{|c|} 
HPDL \\
$(\mathrm{CW})$ \\
$0.810(\mu \mathrm{m})$
\end{tabular} & $\begin{array}{c}\begin{array}{c}\text { Excimer } \\
\text { (pulsed) }\end{array} \\
0.248(\mu \mathrm{m})\end{array}$ \\
\hline $\begin{array}{l}\text { Range of } \\
\text { power } \\
\text { density } \\
\left(\mathrm{W} / \mathrm{m} \mathrm{m}^{2}\right)\end{array}$ & $\begin{array}{c}550-4860 @ \\
100 \text { mm/min }\end{array}$ & $\begin{array}{c}583 \text { - 3357@ } \\
10 \text { mm/sec }\end{array}$ & $\begin{array}{c}\text { 694-4861@ } \\
100 \text { mm/min }\end{array}$ & $\begin{array}{l}500-6773 \\
@ 60-600 \\
\mathrm{~mm} / \mathrm{min}\end{array}$ & $\begin{array}{l}100 \text { to } 1200 \mathrm{~mJ} \\
\text { @ Variable, } 1 \\
\text { to } 200 \mathrm{~Hz} \\
\text { repetition rate } \\
\text { and } 15 \text { to } 20 \mathrm{~ns} \\
\text { pulse width }\end{array}$ \\
\hline $\begin{array}{l}\text { Absorption } \\
(\mu \mathrm{m})\end{array}$ & $470 \pm 19$ & $195 \pm 12$ & $250 \pm 10$ & $177 \pm 15$ & $7.5 \pm 19$ \\
\hline Beam mode & $\mathrm{TEM}_{00}$ & TEM $_{01^{*}}$ & $\mathrm{TEM}_{00}$ & Multimode & Multimode \\
\hline $\begin{array}{l}\text { Wavelength } \\
\text { suitability }\end{array}$ & $\begin{array}{l}\text { Suitable for } \\
\text { surface } \\
\text { modification, } \\
\text { produces large } \\
\text { HAZ and high } \\
\text { material removal } \\
\text { compared to } \\
\text { other lasers but } \\
\text { ideal for macro } \\
\text { machining of } \\
\text { ceramics. }\end{array}$ & \begin{tabular}{|l} 
Suitable for \\
surface \\
modification, \\
ideal for \\
localized heat \\
input due to \\
pulsed \\
processing \\
(reduced \\
thermal shock), \\
produce lower \\
material \\
removal small \\
HAZ, micro \\
and macro \\
machining is \\
feasible.
\end{tabular} & $\begin{array}{l}\text { Suitable for } \\
\text { surface } \\
\text { modification, } \\
\text { ideal for } \\
\text { localized heat } \\
\text { input and high } \\
\text { depth of } \\
\text { penetration. } \\
\text { Produces small } \\
\text { HAZ compared } \\
\text { to } \mathrm{CO}_{2} \text { laser, } \\
\text { micro and } \\
\text { macro } \\
\text { machining are } \\
\text { both feasible } \\
\text { due to small } \\
\text { spot size and } \\
\text { high beam } \\
\text { quality. }\end{array}$ & \begin{tabular}{|c} 
Ideal for \\
surface \\
modificatio \\
n, micro \\
and macro \\
machining. \\
Sufficient \\
material \\
removal and \\
penetration \\
depth.
\end{tabular} & $\begin{array}{l}\text { Low surface } \\
\text { modification, } \\
\text { low processing } \\
\text { temperatures } \\
\text { generated, low } \\
\text { material } \\
\text { removal and } \\
\text { depth of } \\
\text { penetration, } \\
\text { perfect for } \\
\text { micro } \\
\text { machining of } \\
\text { ceramics and } \\
\text { to locally } \\
\text { modify the } \\
\text { surface at scale } \\
\text { of nm. }\end{array}$ \\
\hline $\begin{array}{l}\text { Thermal } \\
\text { loading } \\
\left(\mathrm{KJ} / \mathrm{cm}^{-3}\right)\end{array}$ & 2.57 & 6.73 & 5.50 & 9.83 & 22.24 \\
\hline $\begin{array}{l}\text { Fluence } \\
\text { threshold } \\
\left(\mathrm{J} / \mathrm{cm}^{-2}\right)\end{array}$ & 68 & 128 & 132 & 181 & 0.12 \\
\hline
\end{tabular}


Table 2: Fracture toughness values of $\mathrm{Si}_{3} \mathrm{~N}_{4}$ obtained by using the various indentation fracture methods.

\begin{tabular}{|c|l|l|l|l|}
\hline Indentation fracture methods & Vickers & SENB & CNB & DCB \\
\hline $\mathrm{K}_{1 \mathrm{C}}\left(\mathrm{MPa} \mathrm{m}{ }^{1 / 2}\right)$ & $6.37[6]$ & $9[50]$ & $7.9[50]$ & $4.0[52]$ \\
\hline
\end{tabular}

Table 3: Parameters used for the fibre laser treatment of $\mathrm{Si}_{3} \mathrm{~N}_{4}$ ceramics at the traverse speed of $100 \mathrm{~mm} \mathrm{~min}^{-1}$.

\begin{tabular}{|c|c|c|c|}
\hline Trial No & Power (W) & Power density $\left(\mathbf{W} / \mathbf{~ m m}^{\mathbf{2}}\right)$ & Comments \\
\hline 1 & 75 & 2083.33 & No visual effect \\
\hline 2 & 100 & 2777.77 & Small change in colour \\
\hline 3 & 125 & 3472.22 & Small cracks apparent \\
\hline 4 & 130 & 3611.11 & Small cracks on the edges. \\
\hline 5 & 150 & 4166.66 & Large cracks apparent \\
\hline 6 & 137.5 & 3819.44 & Crack -free \\
\hline 7 & 143.25 & 3979.17 & Crack-free \\
\hline 8 & 150 & 4166.66 & Large cracks apparent \\
\hline
\end{tabular}

Table 4: Presents the ten equations used to calculate the $\mathrm{K}_{1 \mathrm{c}}$ for the as-received surface of $\mathrm{Si}_{3} \mathrm{~N}_{4}$.

\begin{tabular}{|c|l|l|}
\hline $\begin{array}{l}\text { Equation } \\
\text { Number }\end{array}$ & \multicolumn{1}{|c|}{ Equations } & \multicolumn{1}{|c|}{ Equation Origin } \\
\hline 1 & $\left.\mathrm{~K}_{1 \mathrm{c}}=0.0101 \mathrm{P} / \mathrm{ac}^{1 / 2}\right)$ & Lawn \& Swain [53] \\
\hline 2 & $\mathrm{~K}_{1 \mathrm{c}}=0.0824 \mathrm{P} / \mathrm{c}^{3 / 2}$ & Lawn \& Fuller [56] \\
\hline 3 & $\mathrm{~K}_{1 \mathrm{c}}=0.0515 \mathrm{P} / \mathrm{C}^{3 / 2}$ & Evans \& Charles [36] \\
\hline 4 & $\mathrm{~K}_{1 \mathrm{c}}=0.0134(\mathrm{E} / \mathrm{Hv})^{1 / 2}\left(\mathrm{P} / \mathrm{c}^{3 / 2}\right)$ & Lawn, Evans \& Marshall [37] \\
\hline 5 & $\mathrm{~K}_{1 \mathrm{c}}=0.0330(\mathrm{E} / \mathrm{Hv})^{2 / 5}\left(\mathrm{P} / \mathrm{c}^{3 / 2}\right)$ & Niihara, Morena and Hasselman [40] \\
\hline 6 & $\mathrm{~K}_{1 \mathrm{c}}=0.0363(\mathrm{E} / \mathrm{Hv})^{2 / 5}\left(\mathrm{P} / \mathrm{a}^{1.5}\right)(\mathrm{a} / \mathrm{c})^{1.56}$ & Lankford [57] \\
\hline 7 & $\mathrm{~K}_{1 \mathrm{c}}=0.095(\mathrm{E} / \mathrm{Hv})^{2 / 3}\left(\mathrm{P} / \mathrm{c}^{3 / 2}\right)$ & Laugier [58] \\
\hline 8 & $\mathrm{~K}_{1 \mathrm{c}}=0.022(\mathrm{E} / \mathrm{Hv})^{2 / 3}\left(\mathrm{P} / \mathrm{c}^{3 / 2}\right)$ & Laugier [58] \\
\hline 9 & $\mathrm{~K}_{1 \mathrm{c}}=0.035(\mathrm{E} / \mathrm{Hv})^{1 / 4}\left(\mathrm{P} / \mathrm{c}^{3 / 2}\right)$ & Tanaka [59] \\
\hline 10 & $\mathrm{~K}_{1 \mathrm{c}}=0.016(\mathrm{E} / \mathrm{Hv})^{1 / 2}\left(\mathrm{P} / \mathrm{c}^{3 / 2}\right)$ & Anstis, Chantikul, Lawn \& Marshall [52] \\
\hline
\end{tabular}

Table 5: The end $\mathrm{K}_{1 \mathrm{c}}$ values with its standard deviation and range for 5 and $30 \mathrm{~kg}$ load from employing the ten equations for the as-received $\mathrm{Si}_{3} \mathrm{~N}_{4}$ engineering ceramic.

\begin{tabular}{|c|c|c|c|c|c|c|}
\hline $\begin{array}{l}\text { Equation } \\
\text { Number }\end{array}$ & $\begin{array}{c}\text { Average } \\
\mathrm{K}_{1 \mathrm{c}} \text { value } \\
\text { using } 30 \\
\text { kg load } \\
(\mathrm{MPa} \\
\left.\mathrm{m}^{1 / 2}\right) \\
\end{array}$ & $\begin{array}{l}\text { Standard } \\
\text { deviation }\end{array}$ & $\begin{array}{c}\text { Range (MPa } \\
\left.\mathrm{m}^{1 / 2}\right)\end{array}$ & $\begin{array}{c}\text { Average } \\
\mathrm{K}_{1 \mathrm{c}} \text { value } \\
\text { using } 5 \mathrm{~kg} \\
\text { load } \\
(\mathrm{MPa} \\
\left.\mathrm{m}^{1 / 2}\right) \\
\end{array}$ & $\begin{array}{l}\text { Standard } \\
\text { Deviation }\end{array}$ & $\begin{array}{c}\text { Range (MPa } \\
\mathrm{m}^{1 / 2} \text { ) }\end{array}$ \\
\hline 1 & 0.64 & 0.14 & $0.98-0.40$ & 0.10 & 0.03 & $0.04-0.20$ \\
\hline 2 & 2.32 & 0.51 & $1.47-3.15$ & 0.26 & 0.11 & $0.14-0.73$ \\
\hline 3 & 3.71 & 0.83 & $2.35-5.68$ & 0.577 & 0.18 & $0.22-1.17$ \\
\hline 4 & 19.71 & 4.70 & $10.90-29.51$ & 3.71 & 1.28 & $1.07-5.94$ \\
\hline 5 & 46.48 & 9.57 & $26.85-68.82$ & 9.04 & 17.33 & $4.58-13.25$ \\
\hline 6 & 474.68 & 100.27 & $323.84-686.21$ & 131.67 & 58.69 & $49.29-315$ \\
\hline
\end{tabular}




\begin{tabular}{|c|c|c|c|c|c|c|}
\hline 7 & 2162.22 & 594.10 & $\begin{array}{c}1358.40- \\
3488.21\end{array}$ & 558.51 & 214.00 & $206.26-919.94$ \\
\hline 8 & 468.94 & 137.58 & $240.13-828.97$ & 131.49 & 70.26 & $54.52-379.27$ \\
\hline 9 & 746.04 & 218.88 & $382.03-1152.66$ & 21.60 & 11.38 & $9.07-61.50$ \\
\hline 10 & 8.70 & 1.81 & $13.16-5.43$ & 1.71 & 0.59 & $3.66-0.56$ \\
\hline
\end{tabular}

Note: Young's modulus is $310 \mathrm{GPa}$ (as-received surface), average hardness at $30 \mathrm{~kg}$ load is $1489 \mathrm{Hv}$ (14.60 GPa) with a range of $1575 \mathrm{Hv}-1208 \mathrm{Hv}(15.44-11.85 \mathrm{GPa})$ and standard deviation of $69.54 \mathrm{Hv}$ (0.68 GPa), average a is $0.000356 \mathrm{~m}$; standard deviation $0.0000553 \mathrm{~m}$; and average $\mathrm{c}$ is $0.000178 \mathrm{~m}$ and standard deviation of $0.000273 \mathrm{~m}$, average hardness at $5 \mathrm{~kg}$ load is $1106 \mathrm{Hv}(11.32 \mathrm{GPa}$ ) with a range of $707 \mathrm{Hv}-1524 \mathrm{Hv}$ (6.93 $14.95 \mathrm{GPa})$ and standard deviation of 201.69 (1.97 GPa), average a is $0.000856 \mathrm{~m}$; standard deviation $\mathrm{m}$; average c $0.000193 \mathrm{~m}$ with a standard deviation 0.0000428 . The density was $3.15 \mathrm{~g} / \mathrm{cm}^{3}$ [68] and the average grain size of $2 \mu \mathrm{m}$ for the as-received surface.

Table 6: Summery of the results illustrating an increase or decrease in the parameters used for calculating the $\mathrm{K}_{1 \mathrm{c}}$ of the as-received and laser treated $\mathrm{Si}_{3} \mathrm{~N}_{4}$ ceramics.

\begin{tabular}{|c|c|c|c|c|c|c|c|c|c|}
\hline \multirow{2}{*}{ Surface Type } & \multicolumn{3}{|c|}{ Surface Hardness (GPa) } & \multicolumn{2}{c|}{ Surface Crack length $(\boldsymbol{\mu m})$} & \multicolumn{3}{c|}{ Surface K1c $\left(\mathbf{M P a}^{\mathbf{1 / 2}}\right)$} \\
\cline { 2 - 10 } & Average & STVD & & Average & STVD & & Average & STVD & \\
\hline $\begin{array}{c}\text { As-received } \\
\text { surface }\end{array}$ & 10.85 & 1.97 & - & 387 & 85 & - & 1.71 & 0.59 & - \\
\hline $\begin{array}{c}\text { Fibre laser } \\
\text { radiated } \\
\text { surface }\end{array}$ & 11.32 & 1.56 & $\begin{array}{c}4 \% \\
\text { Higher }\end{array}$ & 242 & 40 & $\begin{array}{c}37 \% \\
\text { lower }\end{array}$ & 3.25 & 0.94 & $\begin{array}{c}47 \% \\
\text { Increase }\end{array}$ \\
\hline
\end{tabular}




\section{List of Figures}

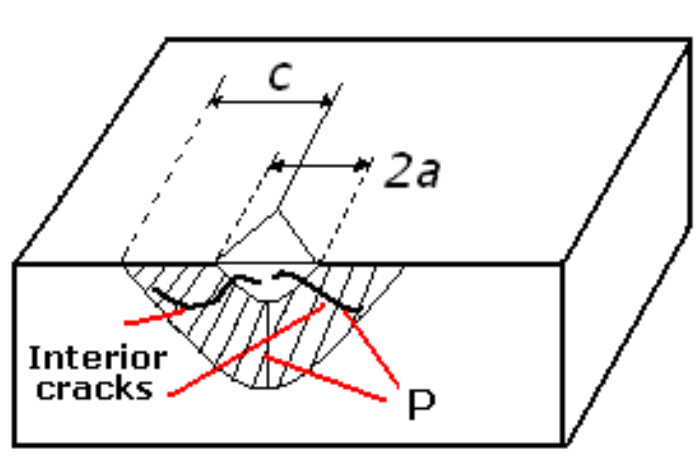

(a)

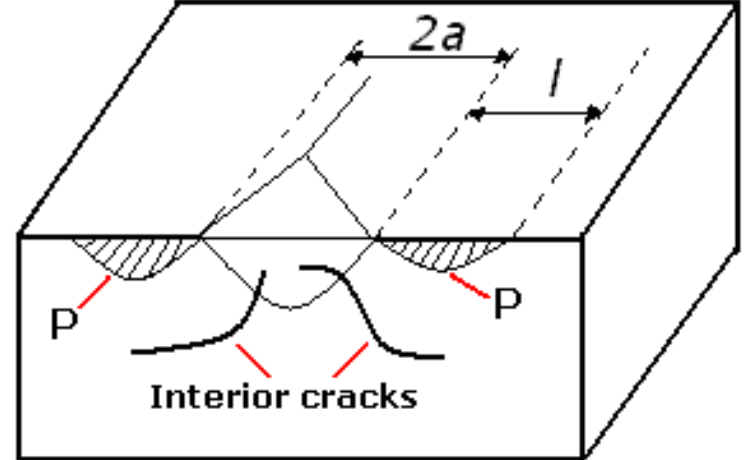

(b)

Figure 1: Median Half-penny crack (a) and Palmqvist crack (b).

Note: $l$ is the surface crack length, 2a is the length of the diamond indent, c is the centre of the diamond to the end of the crack tip and $\mathrm{P}$ is the load impact.



Figure 2: A

schematics diagram of the

experimental set up of the fibre laser treatment. 




(a)

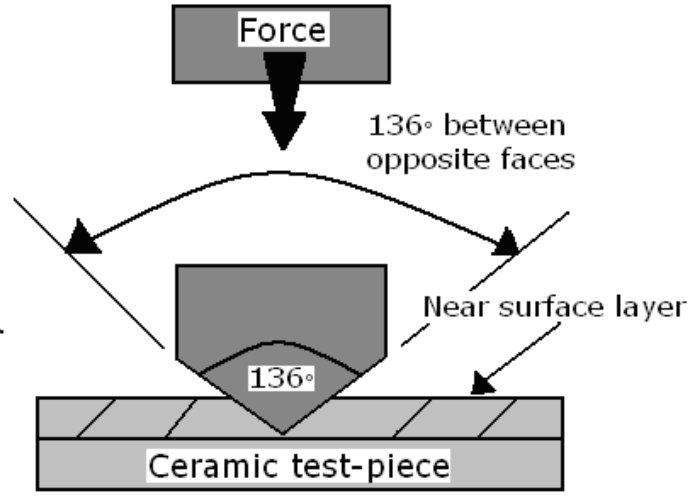

(b)

Figure 3: Schematic of a Vickers diamond indentation with propagation of the cracks (a) and (b) the concept of diamond indentation employed.

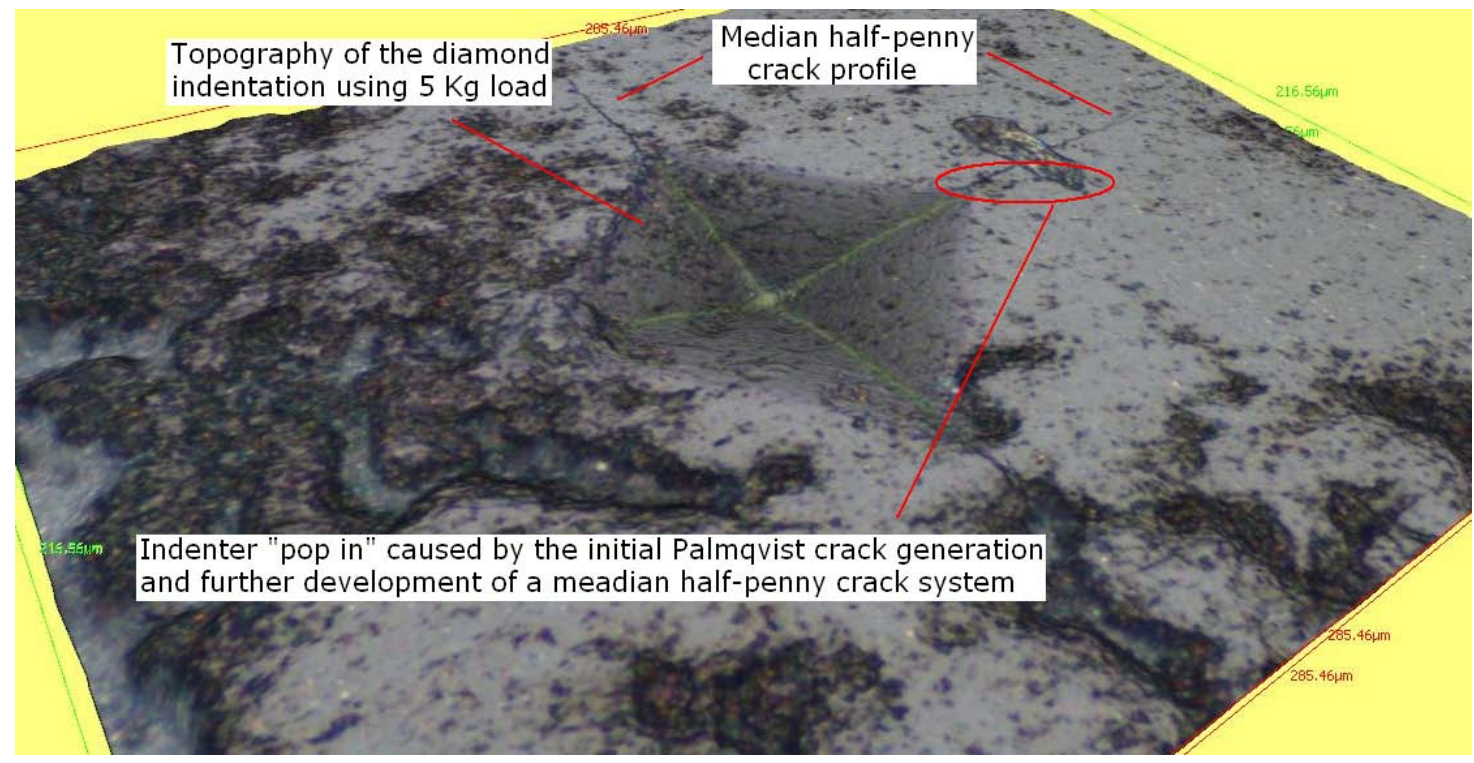

Figure 4: Topography of the Vickers diamond indentation on the as-received surface of the $\mathrm{Si}_{3} \mathrm{~N}_{4}$ ceramics indented at $5 \mathrm{~kg}$, illustrating a median half-penny crack geometry. 


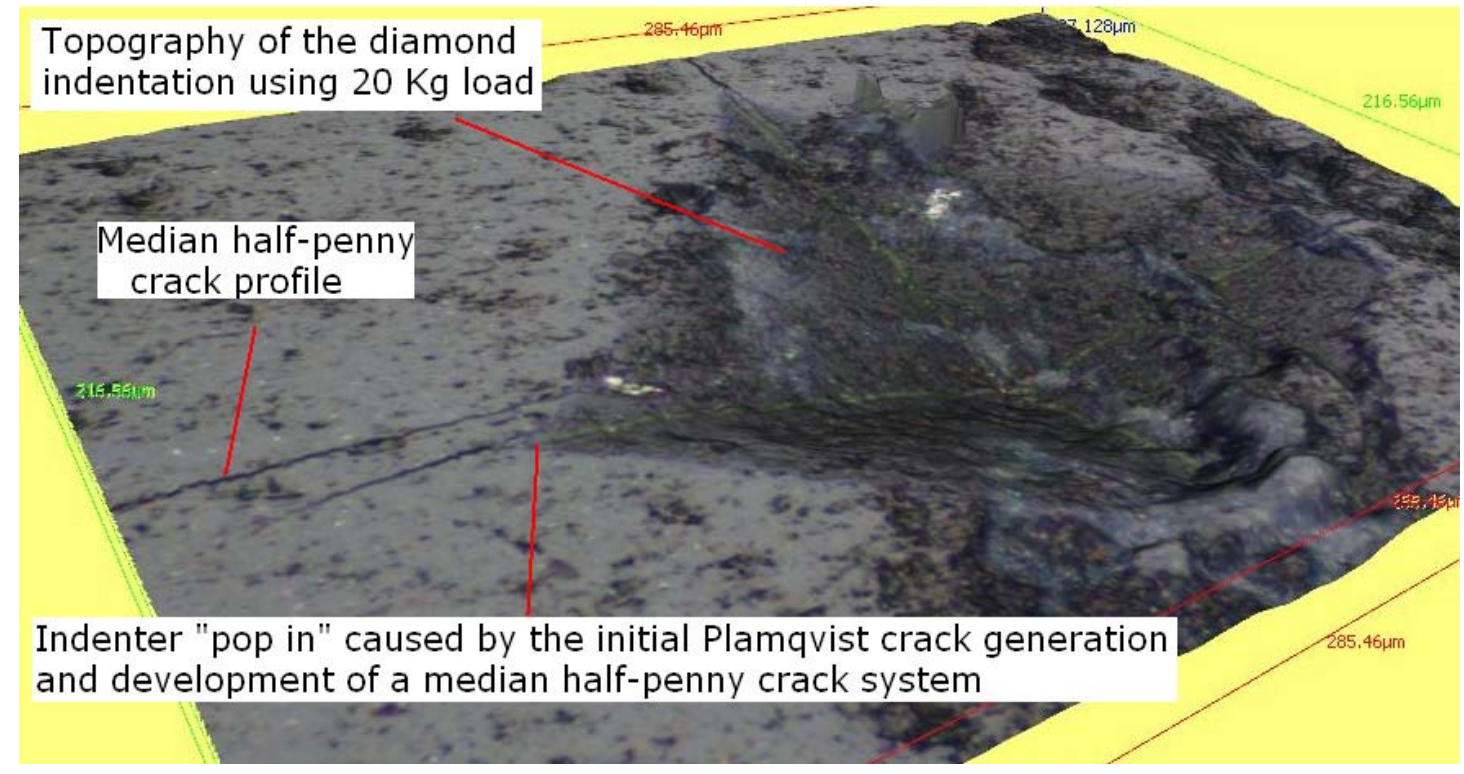

Figure 5: Topography of the Vickers diamond indentation on the as-received surface of the $\mathrm{Si}_{3} \mathrm{~N}_{4}$ ceramics indented at $20 \mathrm{~kg}$, illustrating a median half-penny crack geometry.

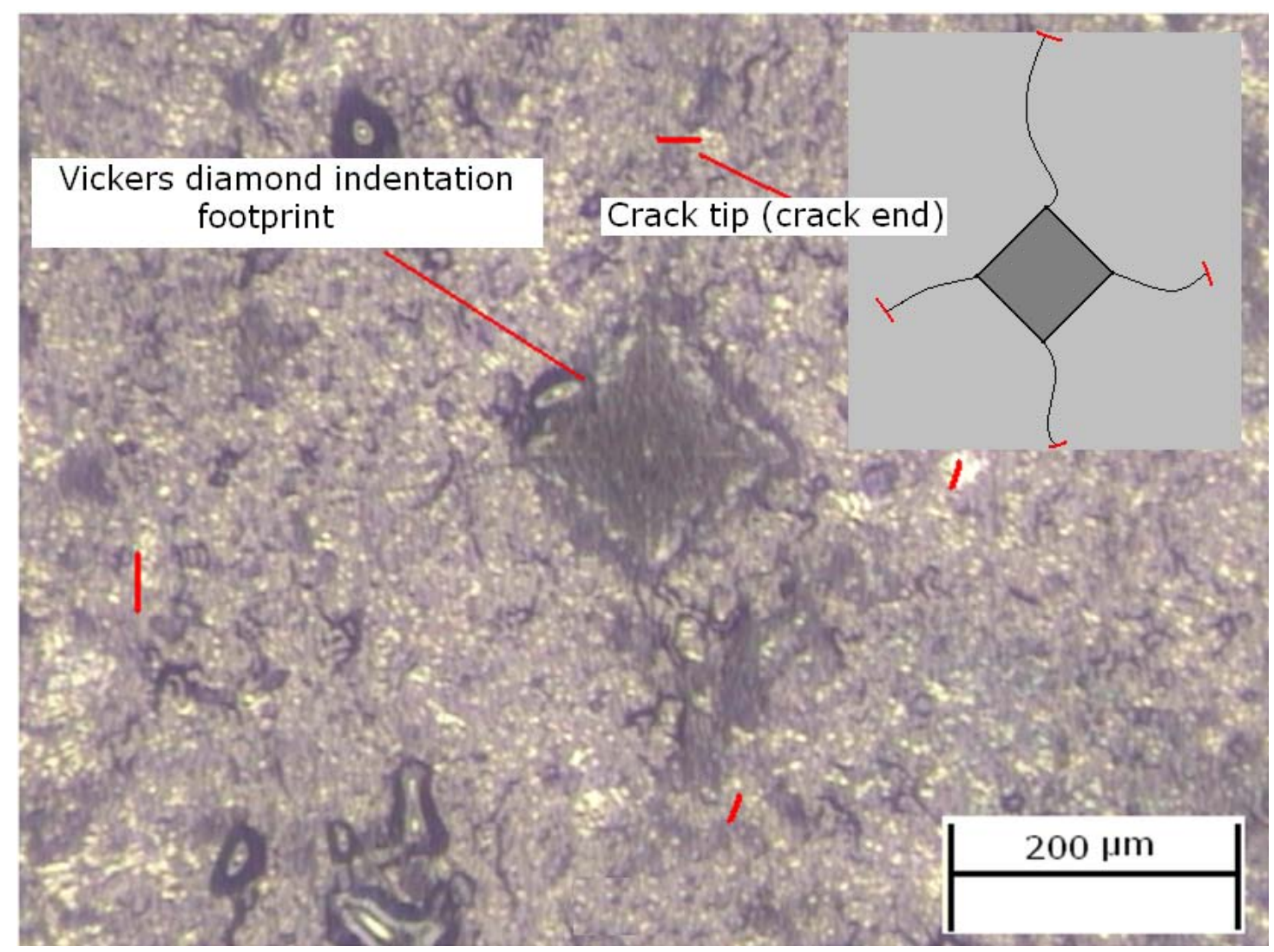

Figure 6: As-received surface of $\mathrm{Si}_{3} \mathrm{~N}_{4}$ ceramics indented with by a $30 \mathrm{~kg}$ load (hardness $=$ 12.67 GPa, crack length $=371 \mu \mathrm{m}, \mathrm{K}_{1 \mathrm{c}}=5.45 \mathrm{MPa} \mathrm{m}^{1 / 2}$ ). 


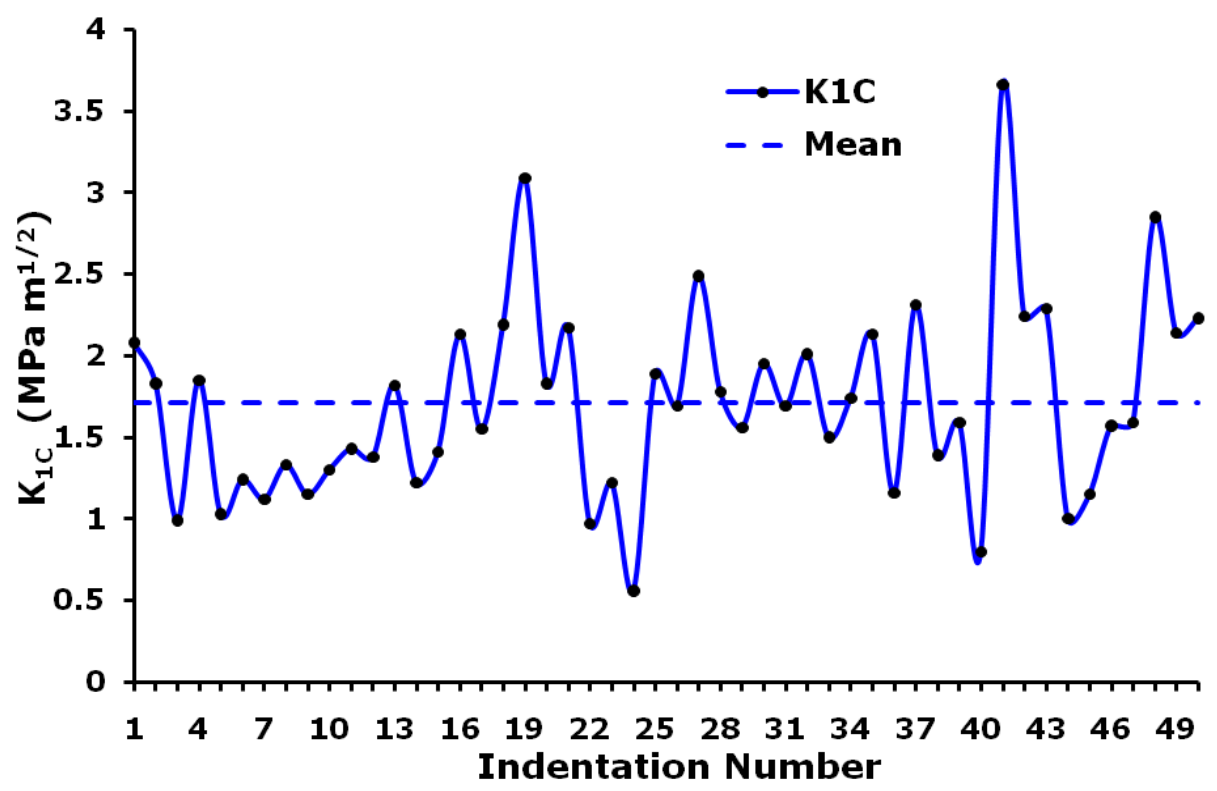

Figure 7: $\mathrm{K}_{1 \mathrm{c}}$ of the as-received surfaces $\mathrm{Si}_{3} \mathrm{~N}_{4}$ ceramics after applying a load of $30 \mathrm{~kg}$.

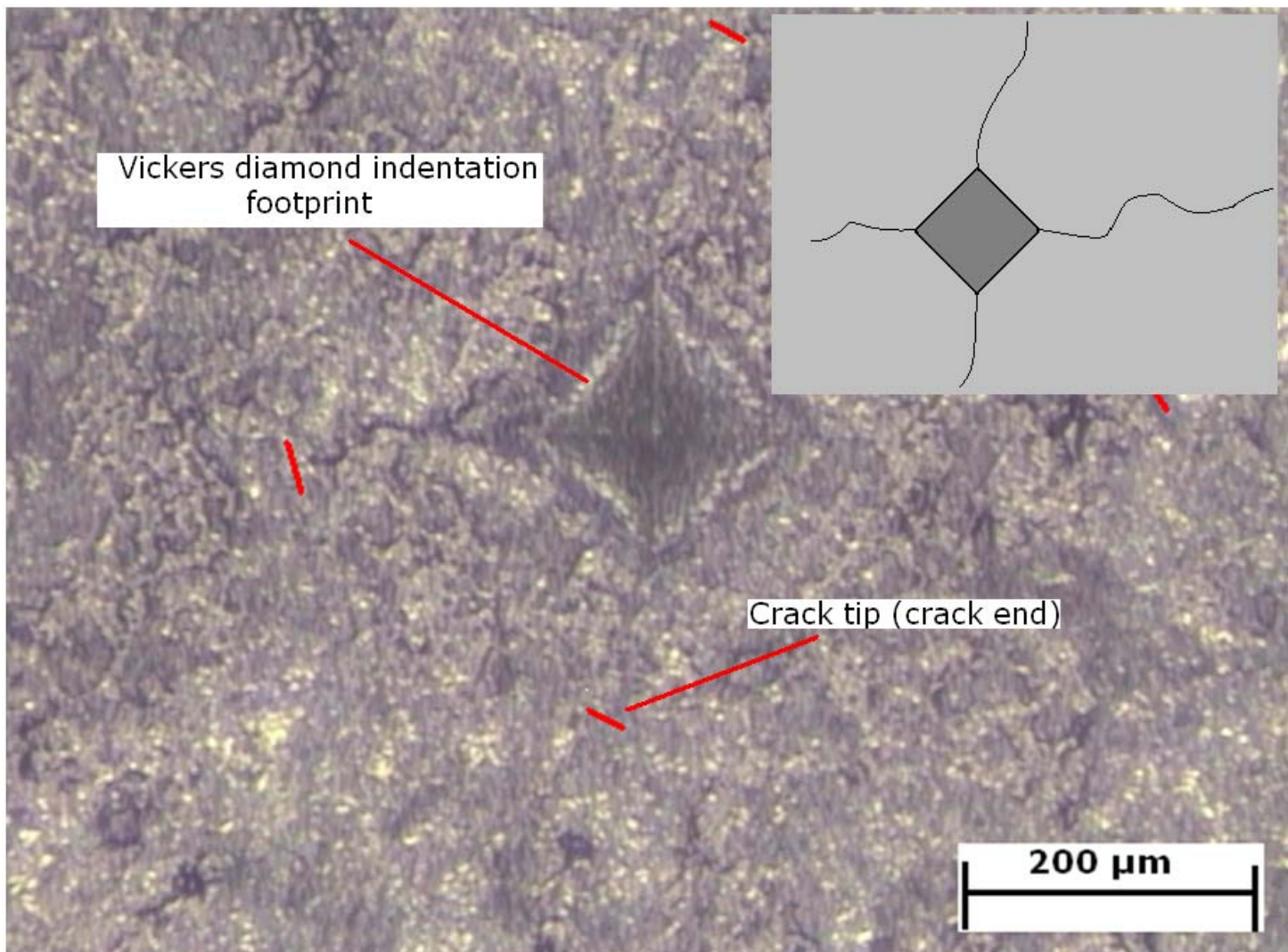

Figure 8: As-received surface of $\mathrm{Si}_{3} \mathrm{~N}_{4}$ ceramic indented by a $5 \mathrm{~kg}$ load (hardness $=8.83 \mathrm{GPa}$, crack length $=391 \mu \mathrm{m}, \mathrm{K}_{1 \mathrm{c}}=1.66 \mathrm{MPa} \mathrm{m}{ }^{1 / 2}$. 


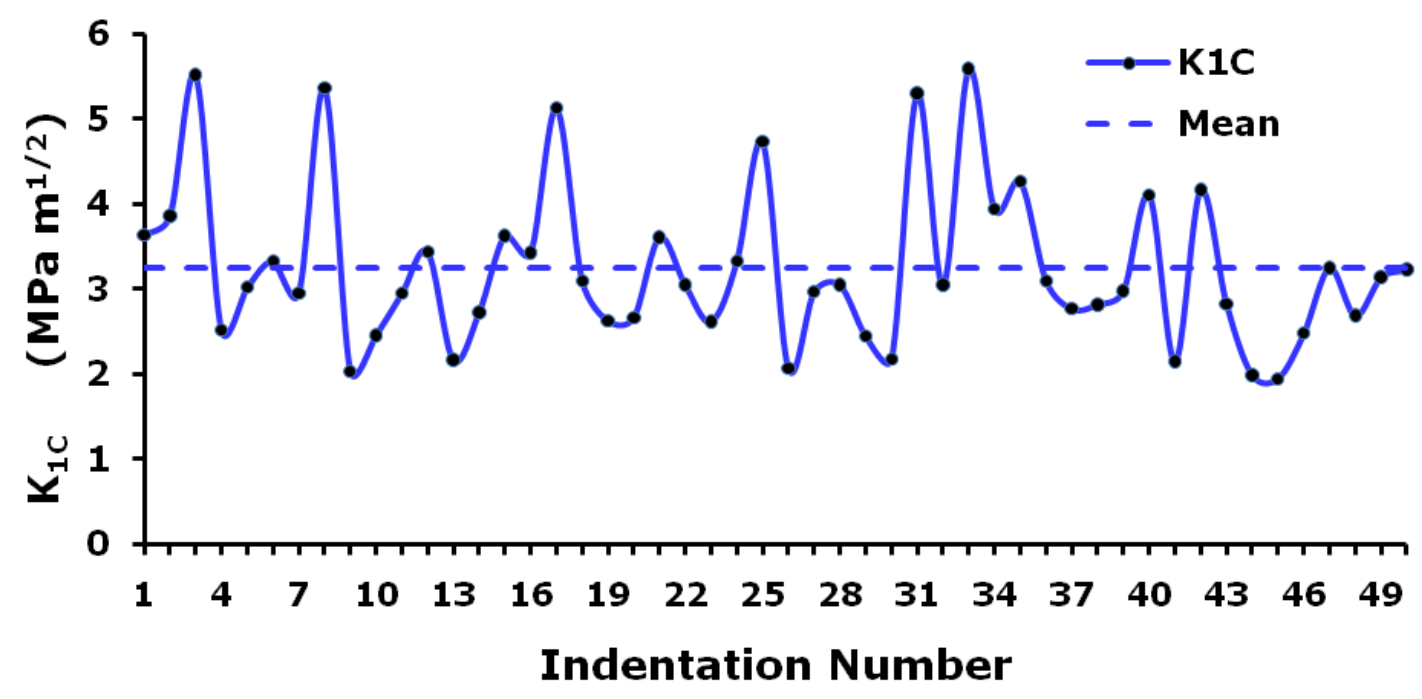

Figure 9: $\mathrm{K}_{1 \mathrm{c}}$ of the as-received surfaces of $\mathrm{Si}_{3} \mathrm{~N}_{4}$ ceramics from applying a $5 \mathrm{~kg}$ indentation load.

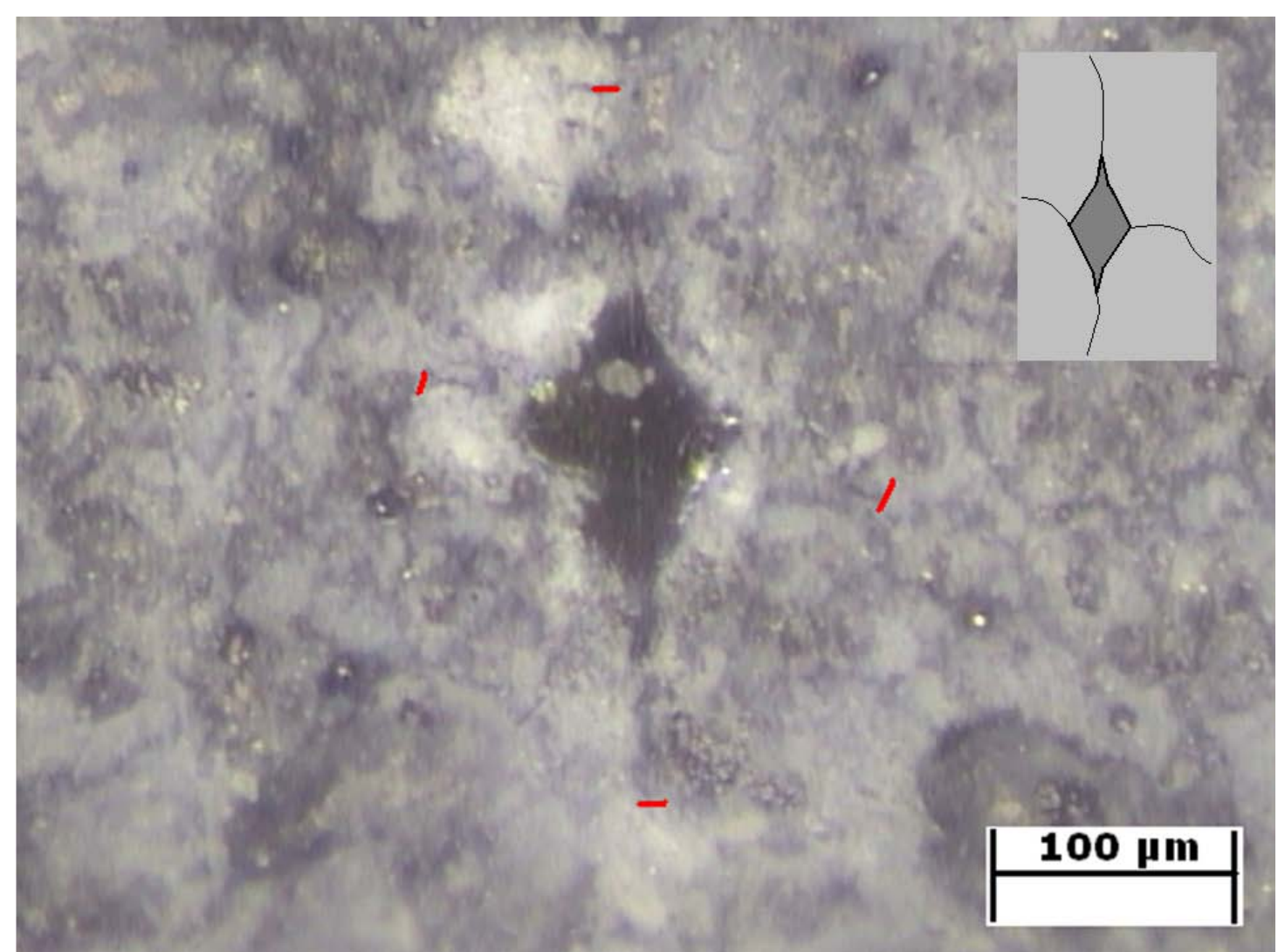

Figure 10: Fibre laser treated surface of $\mathrm{Si}_{3} \mathrm{~N}_{4}$ ceramic indented by a $5 \mathrm{~kg}$ load, laser power $=$ $150 \mathrm{~W}, 100 \mathrm{~mm} \mathrm{~min}^{-1}, 3 \mathrm{~mm}$ post size, $\left(\right.$ hardness $=8.83 \mathrm{GPa}$, crack length $=248 \mu \mathrm{m}, \mathrm{K}_{1 \mathrm{c}}=$ 3.59 MPa $\mathrm{m}^{1 / 2}$ ). 


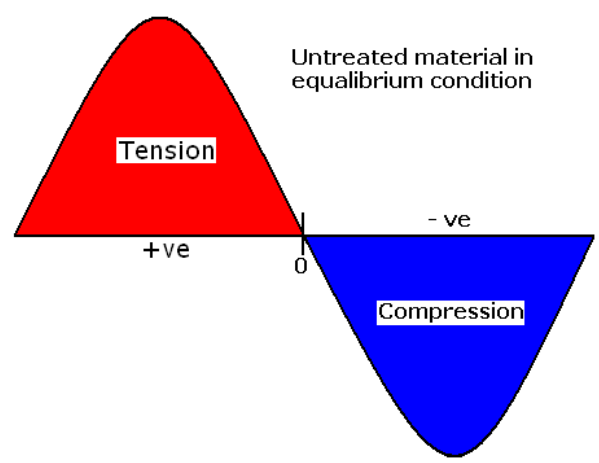

(a)

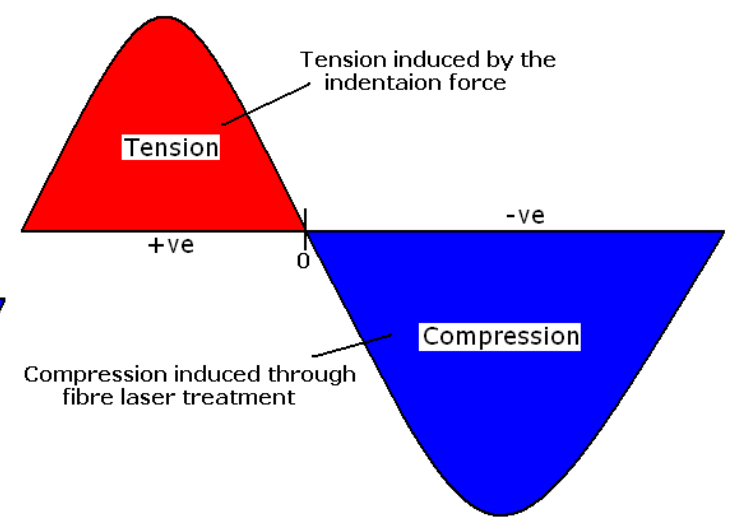

(b)

Figure 11: Diagram of the tension and compression concept where (a) is the state of the ceramic under equilibrium condition and (b) showing the increase in induced compression from the fibre laser treatment.

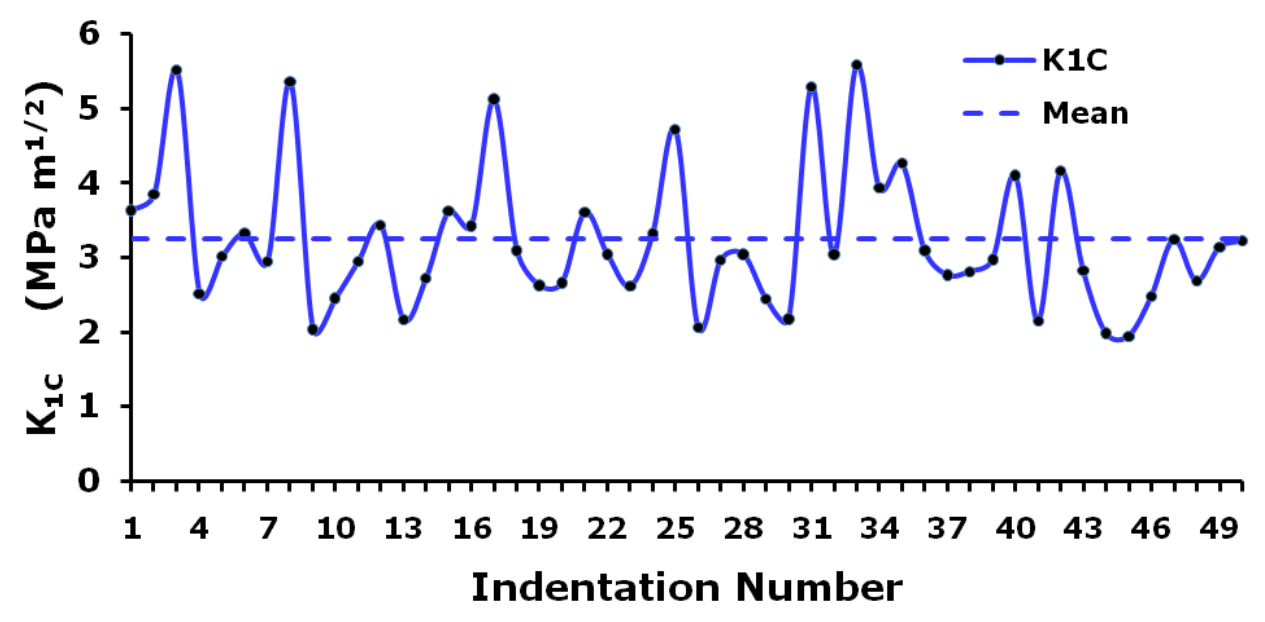

Figure 12: $\mathrm{K}_{1 \mathrm{c}}$ of the fibre laser treated surfaces of $\mathrm{Si}_{3} \mathrm{~N}_{4}$ from applying $5 \mathrm{~kg}$ indentation load.

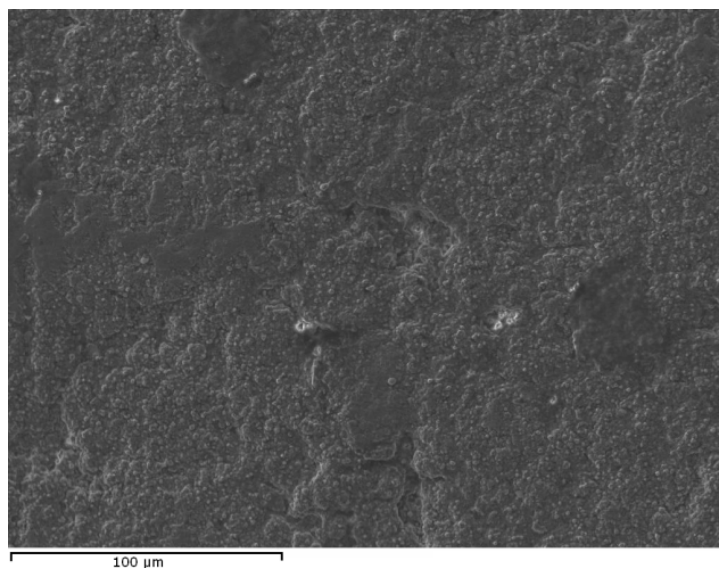

(a)

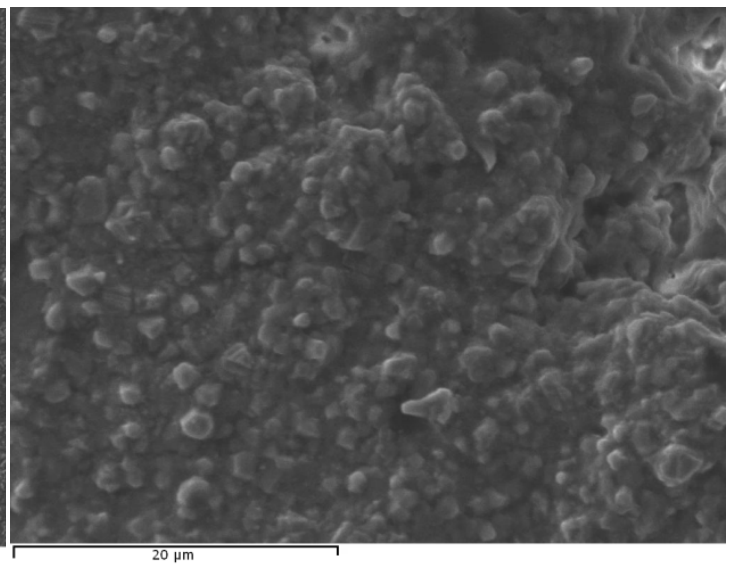

(b) 


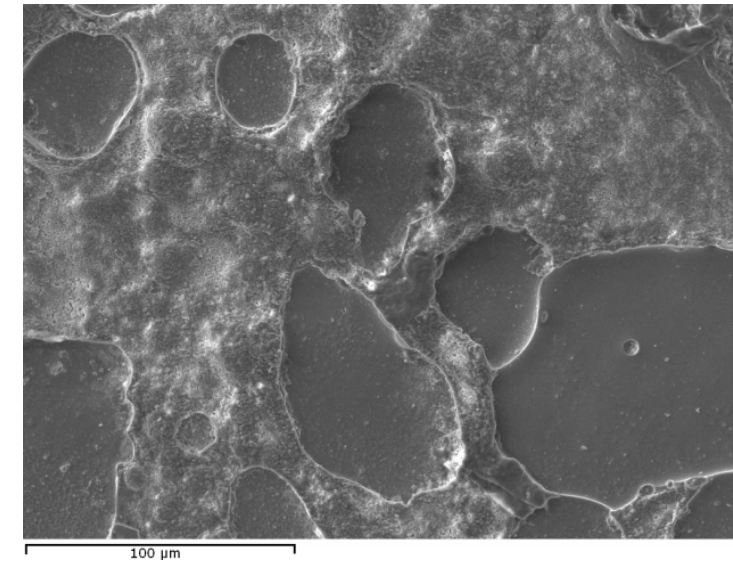

(c)

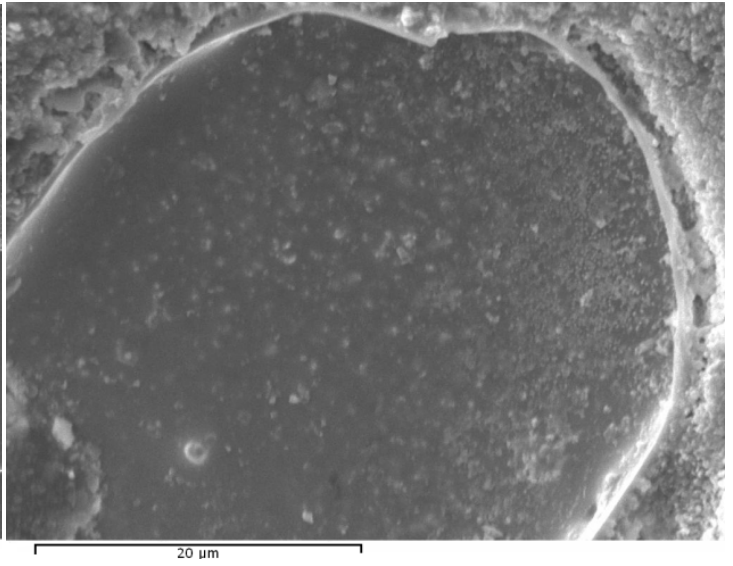

(d)

Figure 13: SEM image of the microstructure of the as-received surface $\mathrm{Si}_{3} \mathrm{~N}_{4}$ engineering ceramic presented in (a) at times 500 and (b) at times 3k resolution as well as the surface morphology and the micro-structure of the fibre laser treated surface of the $\mathrm{Si}_{3} \mathrm{~N}_{4}$ engineering ceramic at times 500 and (b) at times 3k resolution. 